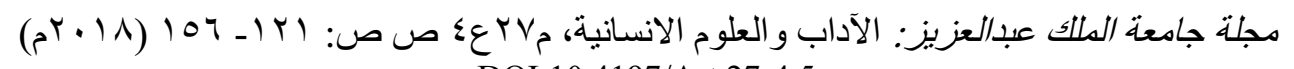

DOI:10.4197/Art.27-4.5

\title{
المعنى الإبداعي للثتعر عند جاسم الصحيح
}

\author{
دا بلدر ندا العتيبي

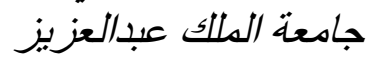

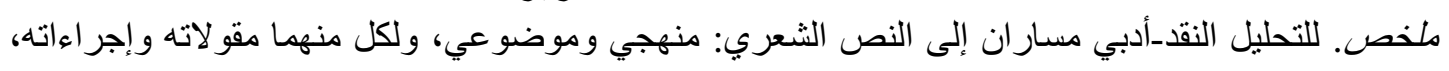

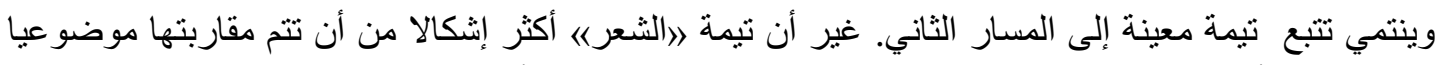

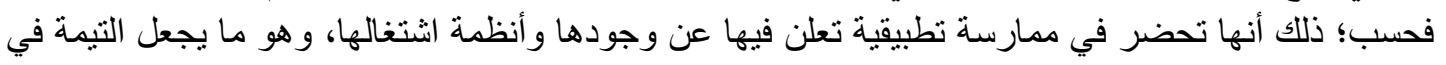

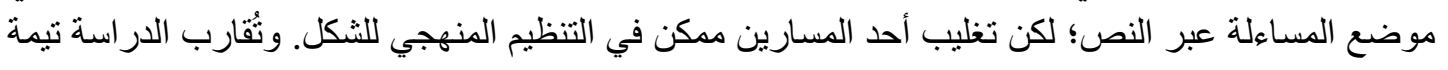

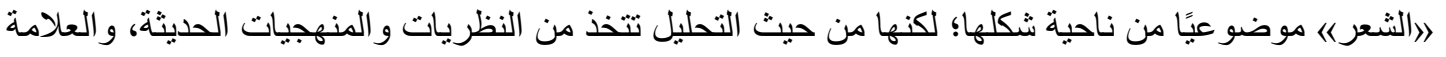

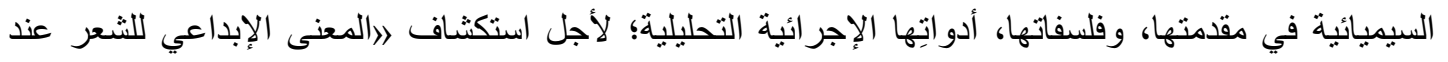

$$
\text { مفاتيح البحث: : المعنى ـ الثعر ـ الإبداع }
$$

الأدب؛ لذا كانت وظيفتها البحتَ عما يجعل من نصٍِ

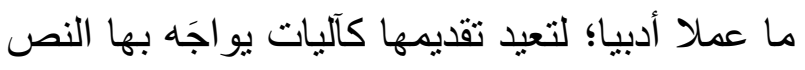

قر ائيا.

غير أن إلماح الأديب/ الثاعر إلى المعطى الغائب

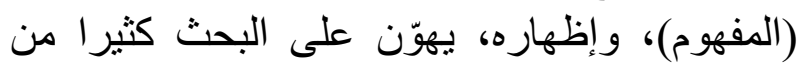

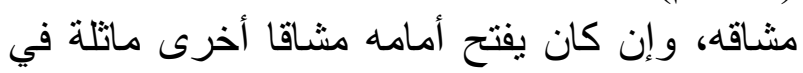

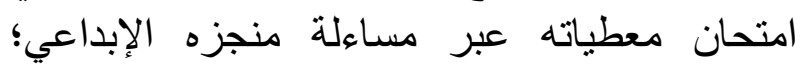

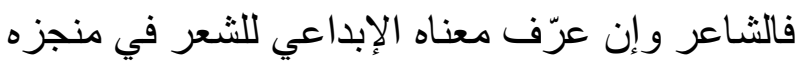

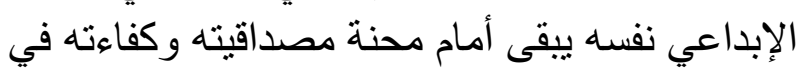

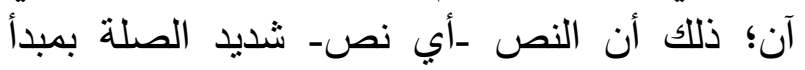

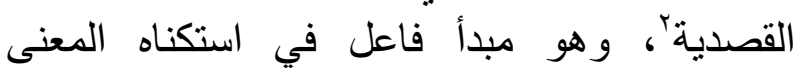

^ بنظر : المعنى الأدبي من الظاهر اتية إلى التفكيك، وليم راي، ترجمة د.

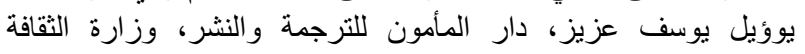

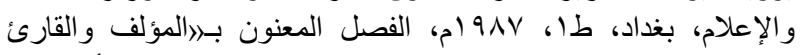

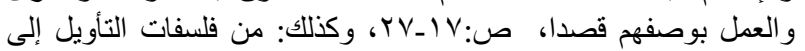
نظريات القراءة ددراسة تحليلية نقدية في النظريات الحديثة، عبد الكريم

\section{المقدمة}

الأدب، بشكل عام، و الثعر خصوصنا، محض مفهوم

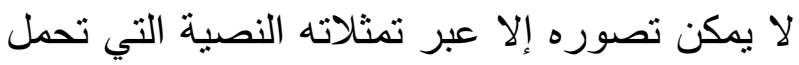

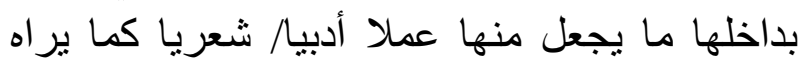

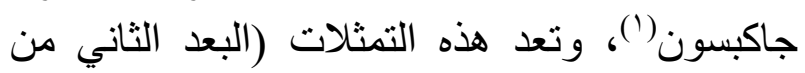
علامة بورس) أساس تفكيك العلامة (النص)؛ حيده هيث

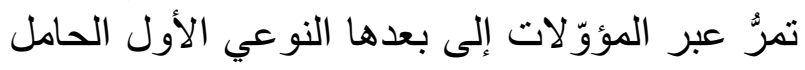

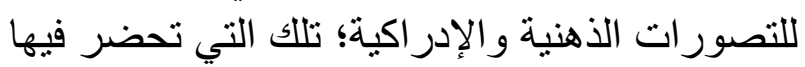

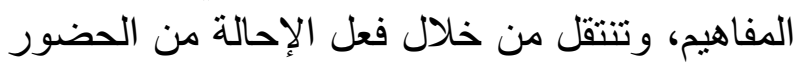

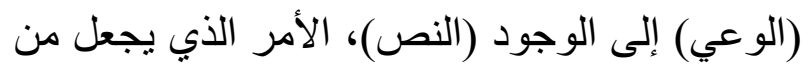

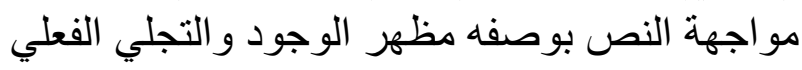
للعلامة ضرورةً للوصول إلى المفي المفاهيم والأبعاد الإدر اكية التي تتأسس عليها، و التي هي شخل نظرية

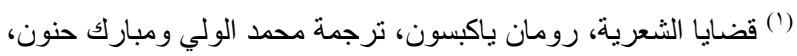

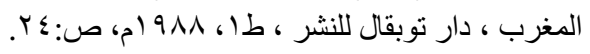


بالطبيعة العلاماتية المنهجية للشعر؛ فاتكاؤه على

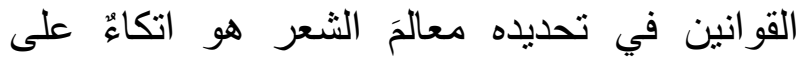

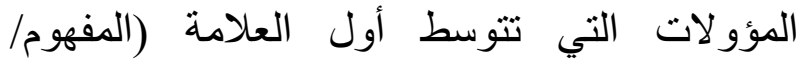

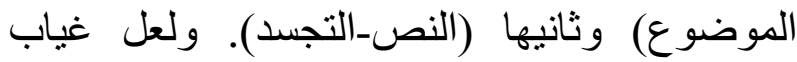
حلقة الاتصال الجوهرية بين الدال (النص) و المدلوله

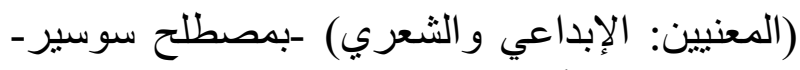
الكامن في مبدأ العلاقة الاعتباطية، وإسنادي الإنية حدوث

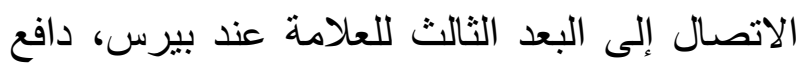
إلى البحث في القوانين الضنامنة المتوسطة، وهي التهي

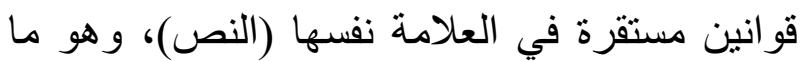
يفسره تنوّع المناهج التي تسعى إلى مقاربة المادة نفسها، بما يؤكد نسبية المادة واحتماليتها. وتلاشي لئي مثل هذا الغياب: الاعتباطية؛ نتيجة وجود ارتباط

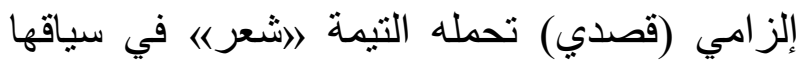
اللغوي، تصريحا أو إلماحا، يغيّر من مسار الدراسة؛ ذلك أن \اهنالك علاقة بين سمة معطاة في الخطاب

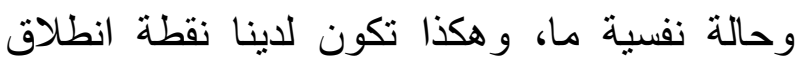

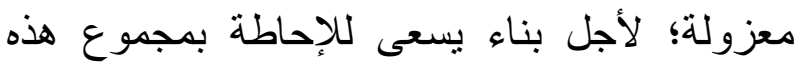

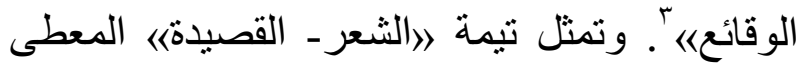

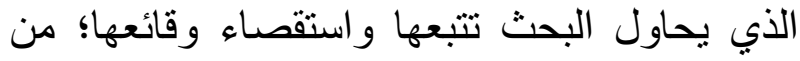
أجل إيجاد 》المعنى الإبداعي للشعر عند جاسم الصحيح)، وهو بحث يتأسس على ما سماه ريفاتير

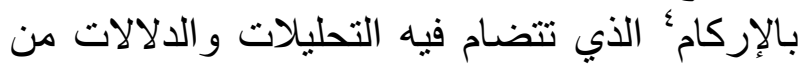

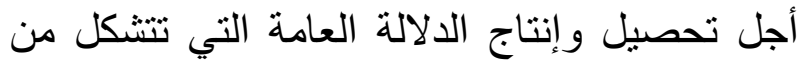

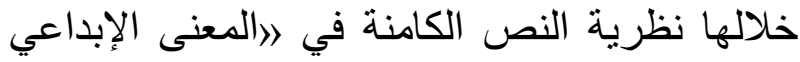
للثعر 《) عند شاعر ما. غير أن الدراسة، وإن عاعن كانت تغامر في الجسد

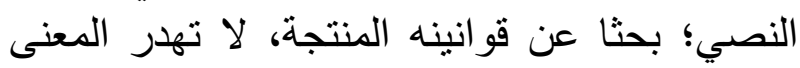

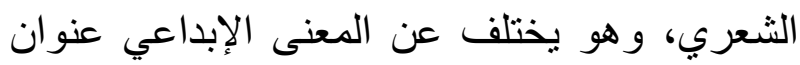

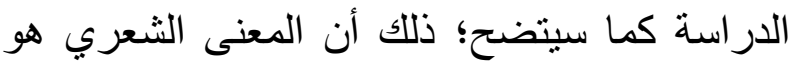

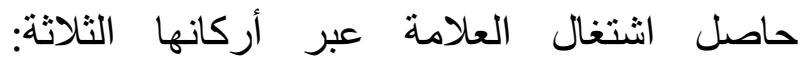

معايير تحليل الأسلوب، ميكائيل ريفاتير، ترجمة وتقديم وتعليقات د.

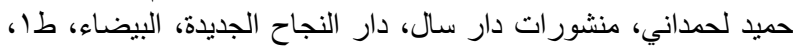

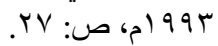

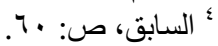

الإبداعي (الأدبي)، ولا شيء أكثر وجاهة وتدليلا

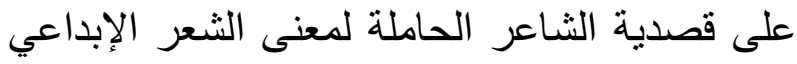
في تصوره من الإعلان عنها من قبله بوصفيه الإبه مرسلا، الأمر الذي حدد للار اسة منهجية استقرائية

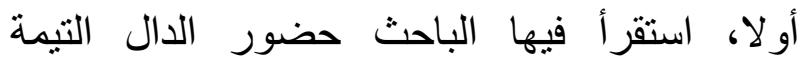

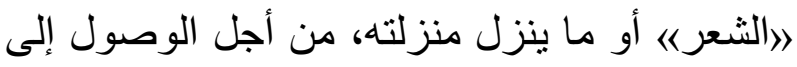

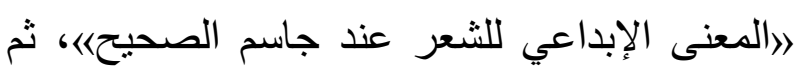

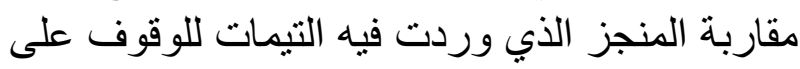
المصداقية، أو الفجوة، بين تصور الدئه المعنى الإبداعي للشعر وتمثلاته في الممارسة التطبيقية. إن التاريخ و الجدل الطويلين في مسألة تحديد المفهوم

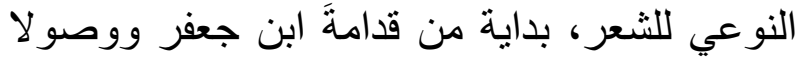

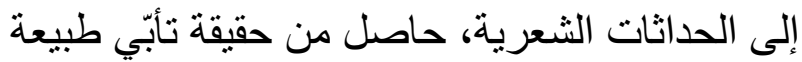
الثعر على الانحصار بأية محددات، و استنادها الآكد

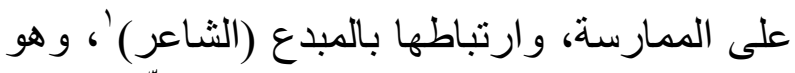
أمرٌ قارُ منذ أرسطو بوصفه أقدم منظّر للشعر

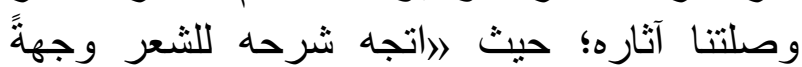

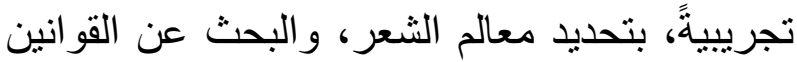

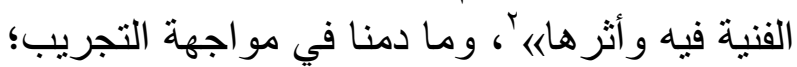

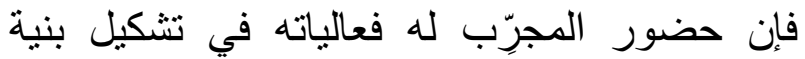

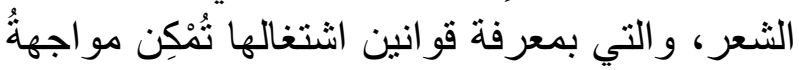

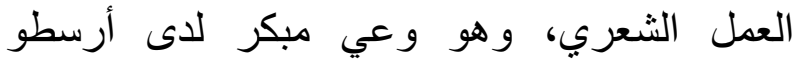

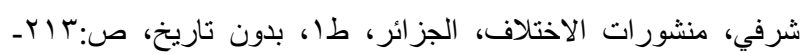

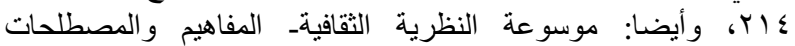

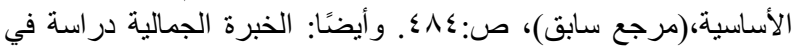

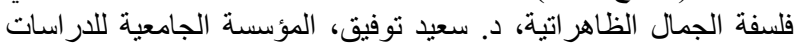

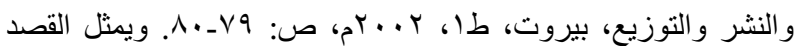

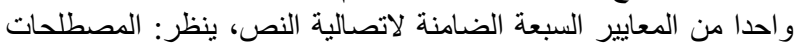

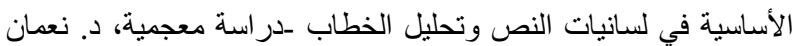

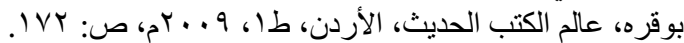

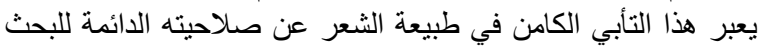

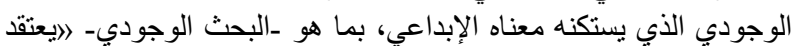

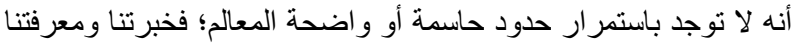

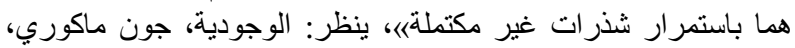

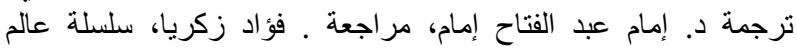

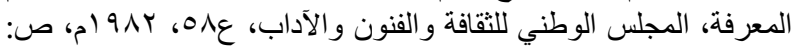

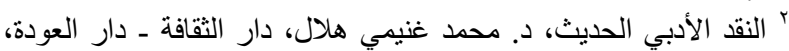

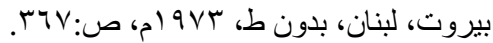


اعتمدتها النزعة الوضعية المنطقية؛ فمعنى جملةٍ ما،

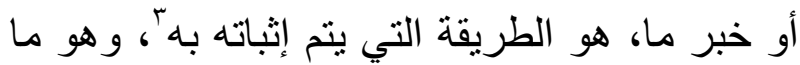

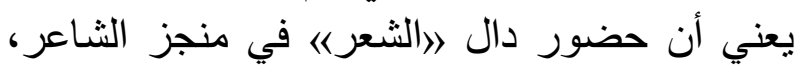
وبوصفه اشتر اطا منه على نفسه (قصدية)، بمثّل عامل إثبات لمعناه المستقر في ذهنه، في الآن الذي فئه

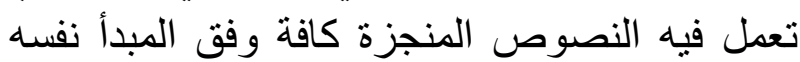
وبالطريقة نفسها. ولقد كان حضور المعنى في الاتجاهات والمناهج

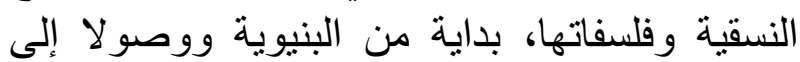
التفكيكية، معينا من حيث مقو لاتها على استثمار ها

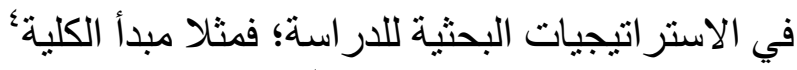
الذي اعتمدته هذه الاتجاهات يمثّل أساس استر اتيجية الإنية

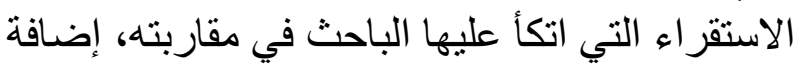
إلى الترداف الحاصل في النظريات الحديثة بين

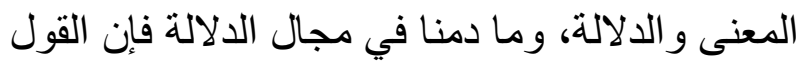

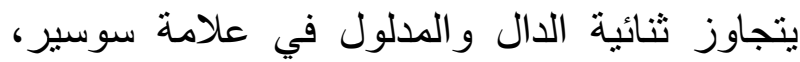

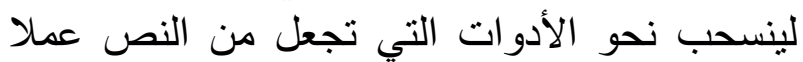

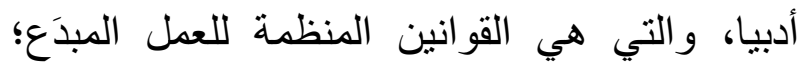

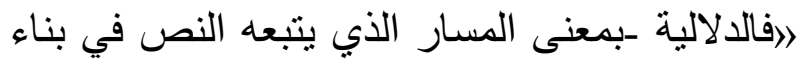

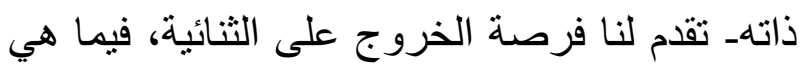

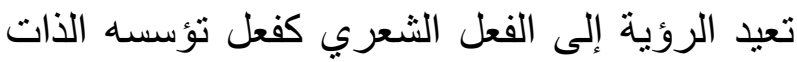

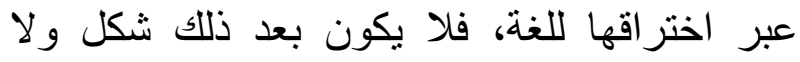

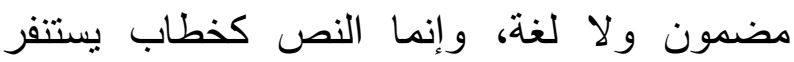

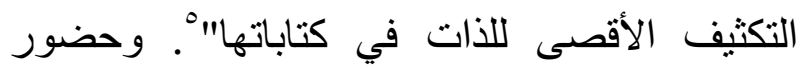
الذات وموقعته في جهة الإرسال يجعل المقصدية الأبية

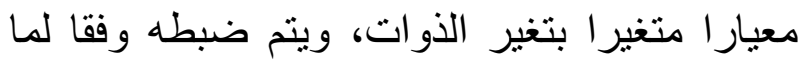
تخصصه به محددات/ مقيدات الجملة، بخلاف ولتهات مصطلح 》المفهوم|نالآي هو مصطلح فلسفي مجرد

" يعد مبدأ الكلية واحدا من المقولات الأساسية للمناهج النسقية جميعا،

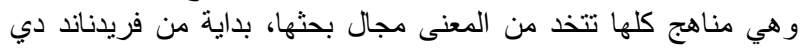

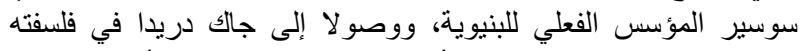

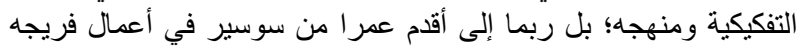

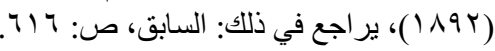

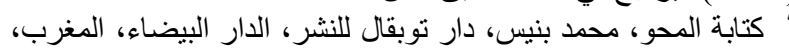

الموضوع_الممثل-القانون، وتصبح تقرقة د.عبد الرحيم الكردي بين القراءتين التفسيرية التأويلية

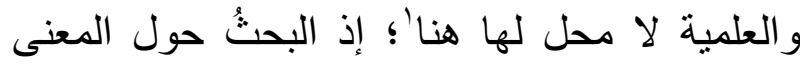

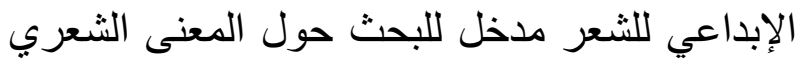

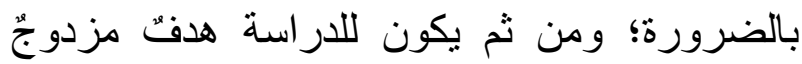

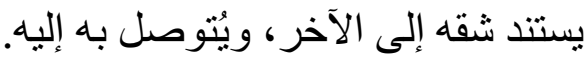

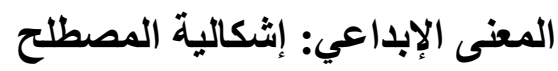

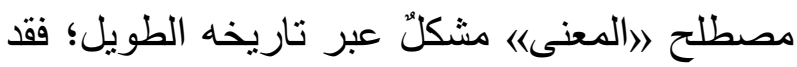

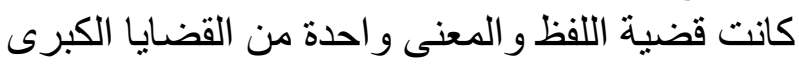

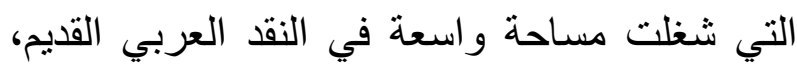

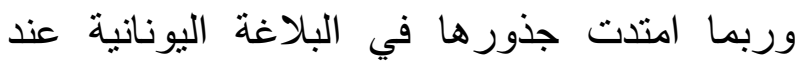

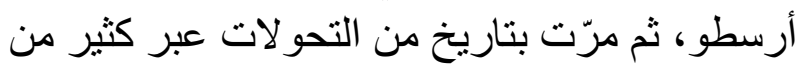
النظريات المختلفة التي شحنته بطاقة دلالية دالية يحاول

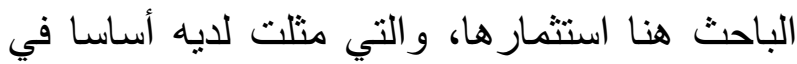

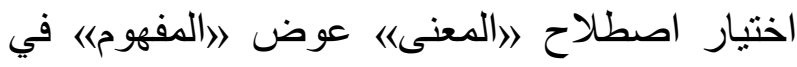

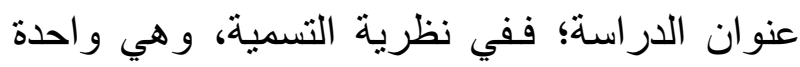

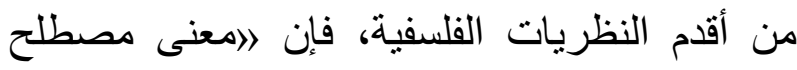

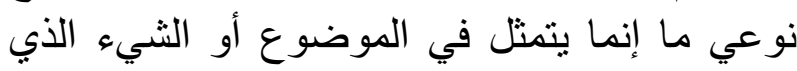

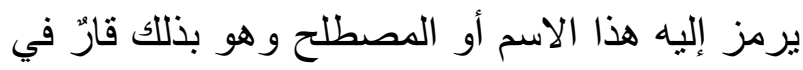

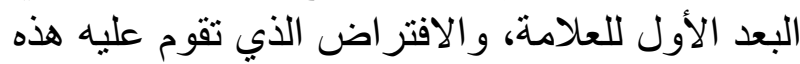

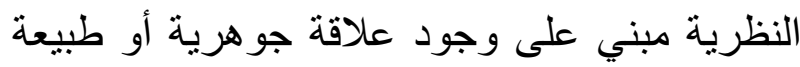
بين العلامة اللغوية (وهي هنا التئنية التئلات النصية)

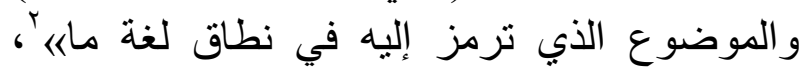

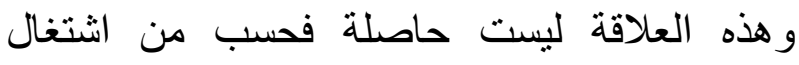

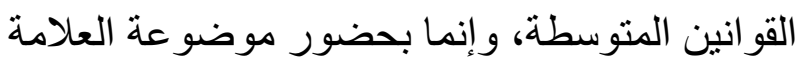
بنفسها من خلال إعلان الثناعر عنها في في منجزه الإبداعي، و التي تنزل بمثابة اشتر اطات تسائل النص إنس

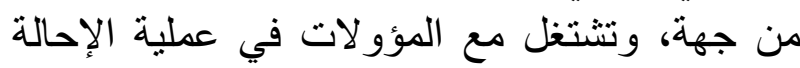

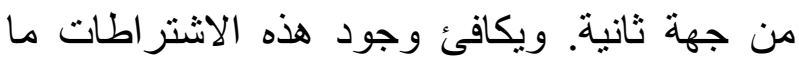
سماه آير بمبدأ الإثبات كواحد من الأسس التي هذه التئ ماني

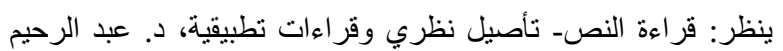
الكردي، سلسلة كتابات نقدية، الهيئة العامة لقصور الثقافة، طا، القئة القاهرة، (r) موسوعة النظرية الثقافيةـ المفاهيم و المصطلحات الأساسية، مرجع

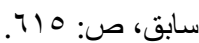


التمثلات العلاماتية التي ينتقل فيها النص من الوعي

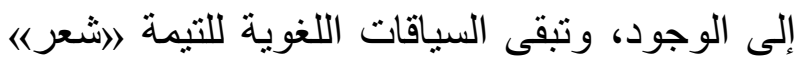
في النصوص، وما تنفتح عليه من تنظيرات ميتانصية (نصوص موازية) . - - الأصول: المبادئ الماورائية

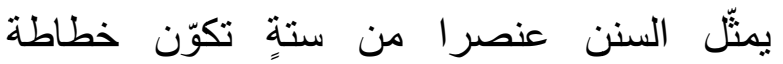
جاكبسون التواصلية'، وقد حدد لها وظيفة الماور اء؛

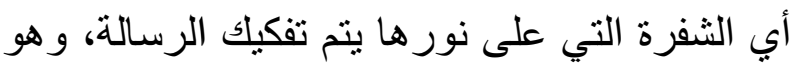

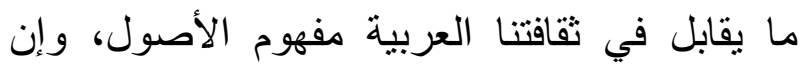
التبس هذا المفهوم بالتحجر و النزوع إلى الى الماضي التي

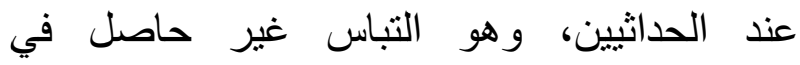
الماوراء، بوصف الأخير بحثا فلسفيا في الماهية؛ ذللك أن الماور اء يعني الغيبيات و الذهنيات و العينيات

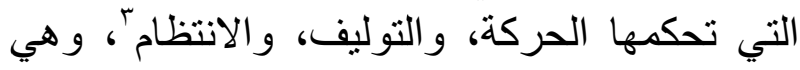

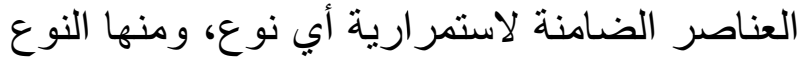
الثعري أيضنا. وعلى كلٍ، فإن للمرسلَة الأدبية مجموعة من المبادئ الماورائية التي تتأسس عليها. ويصرح 》اجاسم الصحيح|ن بمبادئه الماورائية التي لئي

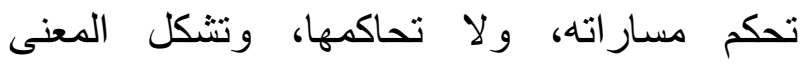

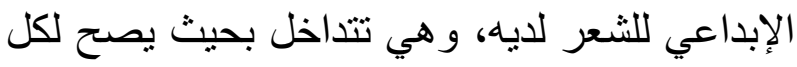

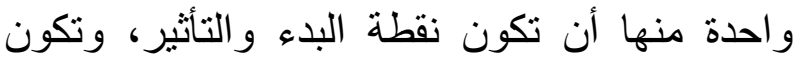

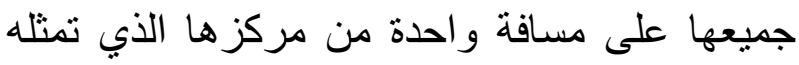
تيمة 》الثعر|《، كما تظهر في الثكل الآتي :

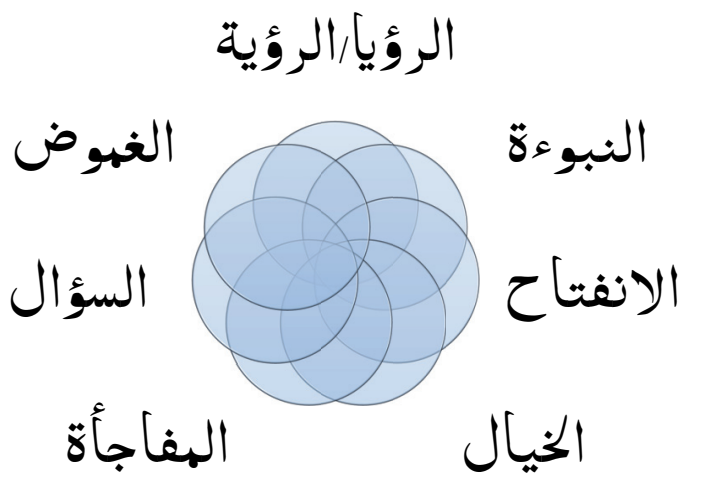

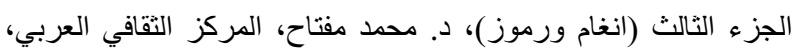

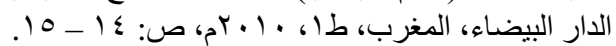

ربما لا يصلح تقييده وتحديده ليظل سابحا في الكليات، ويعطي هذا التغير المستمر للمعنى حقوق ونه لهاه

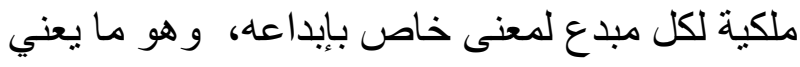

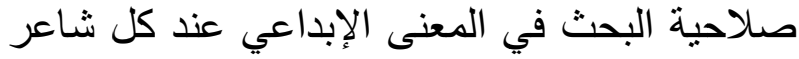

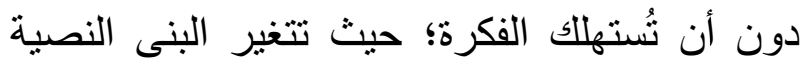
بتغير مرسليها، وتصبح لكل نص نظريته الخاصة، فئه

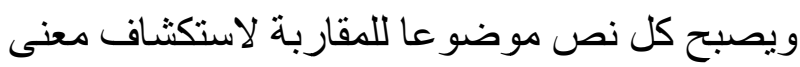
مرسله الإبداعي. ولكي. وإن كانت المقاربة الموضوعية من حيث حيث تيمة

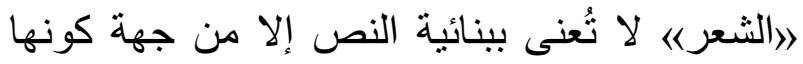

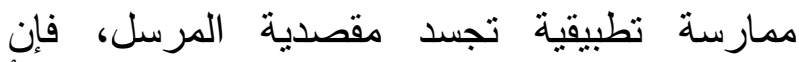
》المعنى《) كمصطلح -و هو مضمون المقصدية- معبّأِ

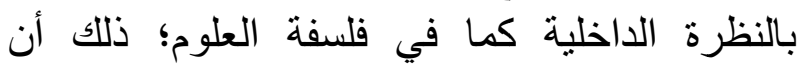

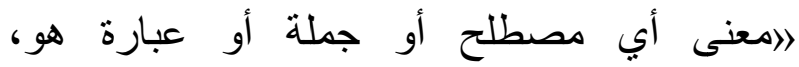
بالضرورة والاقتضاء، معنى موجود في داخل هذا

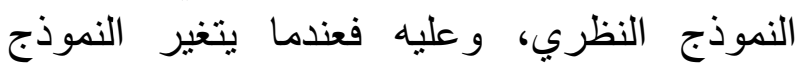
النظري تتغير كذللك معاني المصطلحات المتضمنة

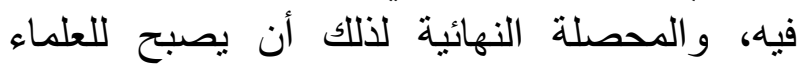
أصحاب النماذج النظرية العلمية المختلفة رؤى الهی مختلفة للعالمه'، ورذا يعني مشروعية مثل هذه الدراسة، وضرورة توزعها بين الموضو عية شكلا، و العلاماتية (النسقية) تحليلا؛ فهي تبحث داخل منجز شعري عن المعنى الإبداعي للشعر من خلال تيمة

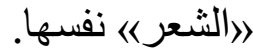
ويمكن اكتشاف 》المعنى الإبداعي للشعر عند جاسم

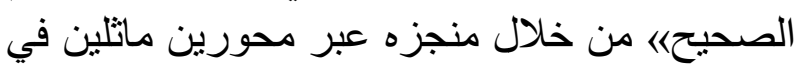
المبادئ وتجلياتها، أو بشيء أكثر دقة ومنهجية مجية: ـ المبادئ الماور ائية.

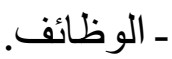
حيث المبادئ الماورائية تشكل الوعي الذي تتجلى

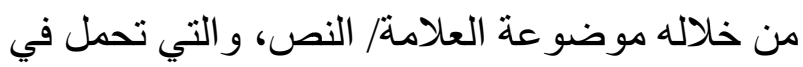

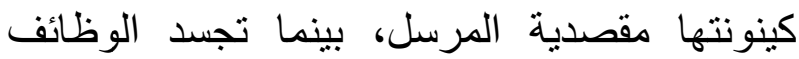

موسوعة النظرية الثقافيةـ المفاهيم والمصطلحات الأساسية، مرجع

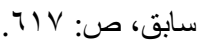


هو يومي وجزئي مجرد وهم مضلل في ضوء

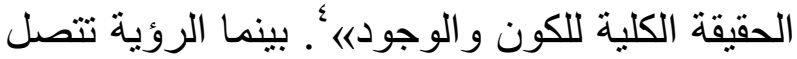

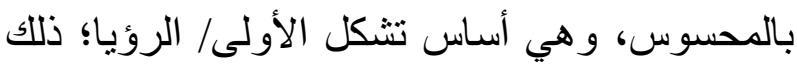
أن \المثول البصري لموضو عات العالم خلق مفهوم

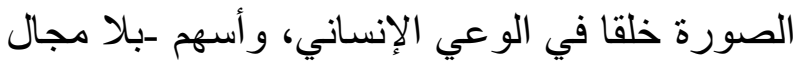
للثك- في تأسيس فاعليات لغوية بعينها، فأبدا لم يكن الأن

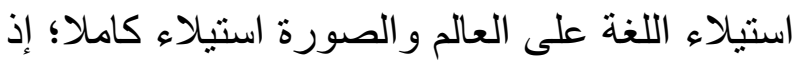

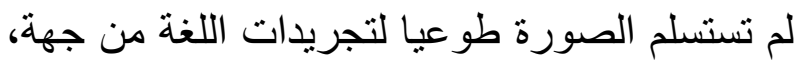
وظل العالم وموضو عاته على مثوله البصري من من اله جهة أخرى، وفضلا عن هذا وذاك ظلت الت الرؤية أداة

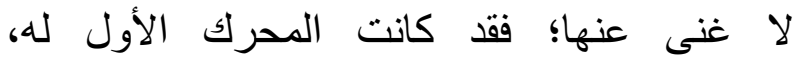

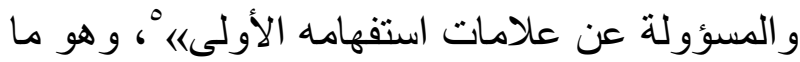

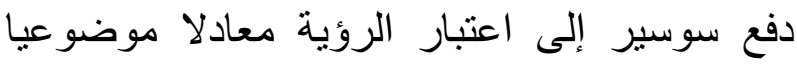

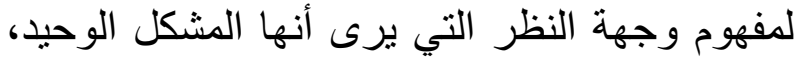

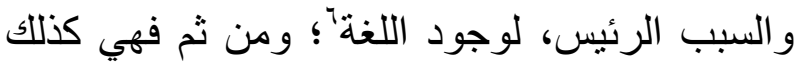
الأساس في وجود العمل الأدبي، واعتباره أصلا وو اقعا لنفسه.

ولعل ارتباط الرؤية بالإدراك، و والرؤيا بتشكيل الوعي، و علاقة كليهما بالذات في تجربتها مع العالم المجهول؛ لتحوله إلى معلوم جديد في أبد إلد استمراري متعال على الاستنساخ، جعل منهما أساسا

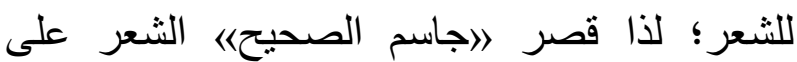

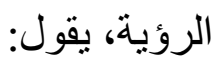

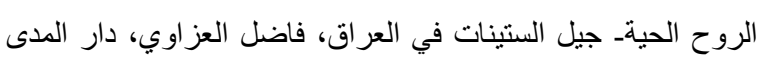

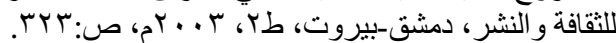

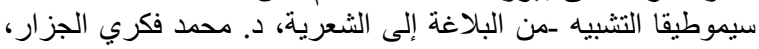

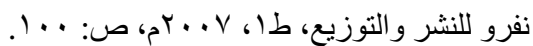

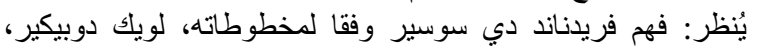

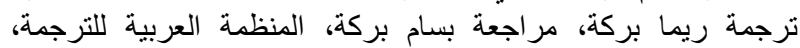

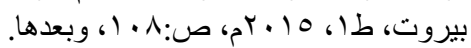

المبادئ الماورائية للمعنى الإبداعي للتيمة 》شعرش

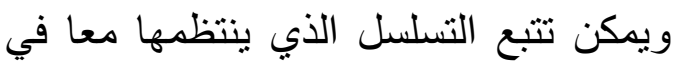
أربعة محاور رئيسة متداخلة يصح أن تتبادل جميعا مو اقع الفعل و الاستجابة، وهي: رونية

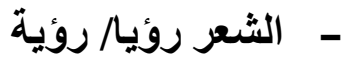

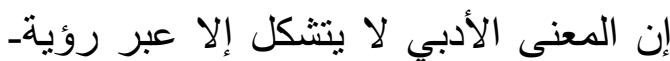

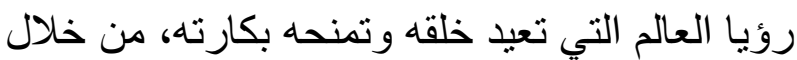

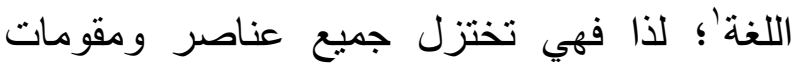

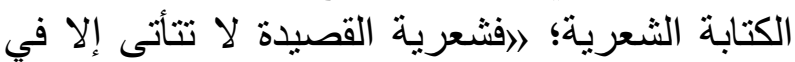

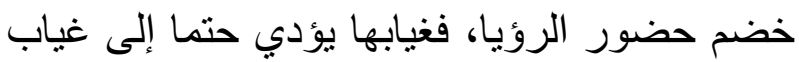

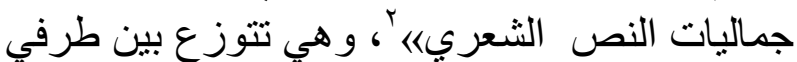
الإرسالية الأدبية: مبدع ومتلقي؛ حيث المعنى الأدبي

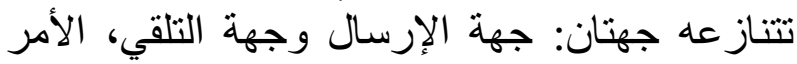
الذي يجعل من طبيعة الشعر الرؤيوية استحضار ها

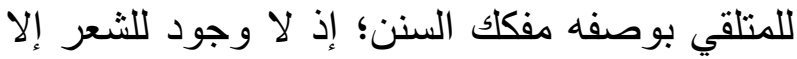

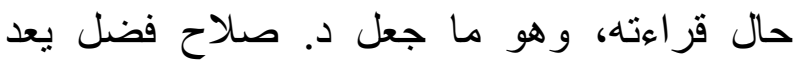

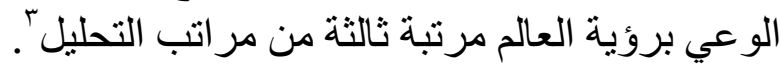

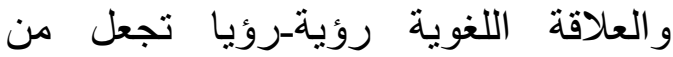

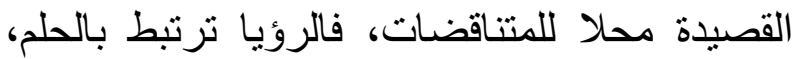
تبحث عن الغيبي والمخفي؛ ومن ثم فهي تنفصل عن عالم المحسوسات، ويبقى لاعالم الثاعر وفق هذئ تهن الرؤيا عالما مصاغا صياغة خاصة داخل ولمات حلم يوحد

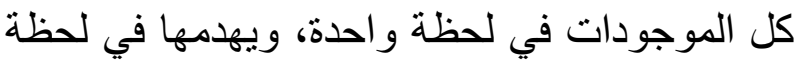

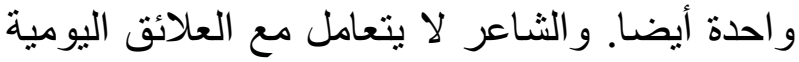
السائدة لغرض تأكيد هذه العلائق؛ ولكن من أجل الحل

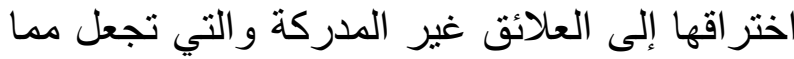

' يُنظر في المصطلح: موسوعة النظرية الثقافيةـ المفاهيم و المصطلحات

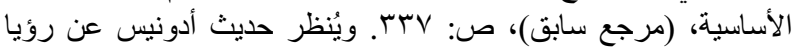

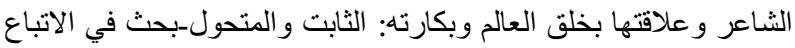

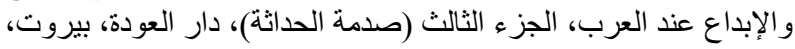

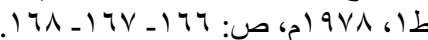

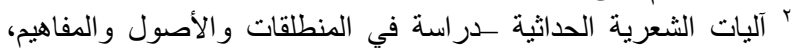

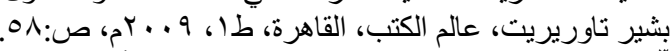

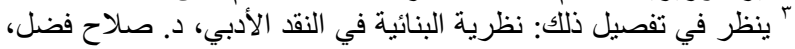

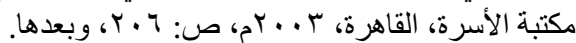




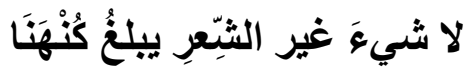

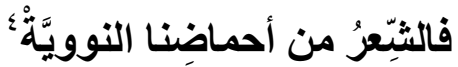

هذا الخرق الدائم الذي تحدثه الرؤية/ الرؤيا

يجعل الثعر نقيضا دائما للطقس و المؤسسة ، وبهذا تكفل لله معناه الإبداعي القائم على كسر المعيار وتحرره من ثبوته وجموديته، وتمكنه من امتحان الأنظمة القائمة على التقليدية، وأولها النظام الخليلي؛ ليخرج الثعر من طوقها الذي أبقاه في أسر التقليد، ونحاه عن مفهوم الإبداع الذي هو باختصار كسر” للألفة كما يراه شكلوفسكيْ؛ ومن ثم تأتي المفاجأة عنصر ا استلهمه المعنى الإبداعي للشُعر عند 》(جاسم الصحيح《) بوصفه عنصرا قارا في طبيعة الفن؛ فالألفة والتوقع يخلقان الرتابة، وهما تجليان لواحدية النظام وسلطوية القالب اللتين تسوقان نحو إهدار القيمة النصية من خلال تعرية المعنى الثُعري بإبقائه أفقا سطحيا و إفقاد القراءة لذتها التي ينشط معها الذهن؛ ذلك أن 》التوقع يمكن أن يؤدي إلى قراءة سطحية؛ بينما سيجبر عدم التوقع على الانتباه، عندئذٍ

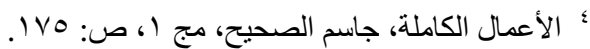

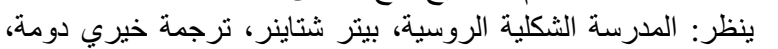

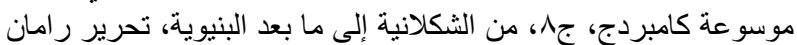

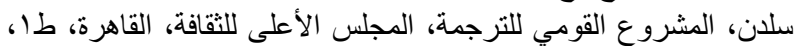

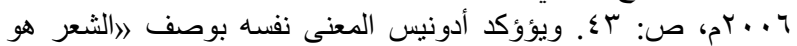

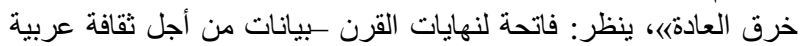

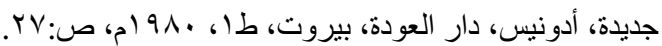

\section{ما الثعر إلا روئيةٌ أسكنتن في جسدِ (القيصرِ) روحَ (المسيخ)'}

فرؤية الثاعر ورؤياه هي التي تمنحه حريته

التي تسري فيه كروح (المسيح)؛ ذلك أن خالثعر هو العمق الروحي و النفسي للإنسان في تحولاته التاريخية و الثقافية والاجتماعية، وهي رؤية لا تقفز على النظرية الأدبية، و لا تتسيج بها؛ لكنها تجعل من الشعر المعادل الموضوعي للحياة، وهو أمر صعب بصعوبة الحياة نفسهاه، وليست ماهية الحياة غير الوجود الإنساني، وعيا وجسدا، وتثتغل الرؤية في منطقة الوعي كما تشتغل على خارطة الجسد؛ ليصبح دال الجسد دالا شعريا بامتياز، عبر جميع

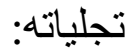

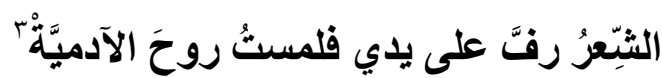

فدال (اليد)، وإن كان دالا حسيا جسديا، يمنحه الثعر نفخة روحية تعيد الدم في أوصاله؛ فتتنشش اليد وتتحرك، والحركة ليست إلا أساس المبادئ الماور ائية التي تشكل الرؤية خلاصتها، و لا تدب الحركة إلا حين تخترق الروح الجسد، وهنا تتحقق الحياة والوجود الإنساني معا؛ ليصبح الثعر بهذا سر كنه الإنسان روحا، وحمضه النووي مادة

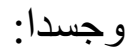

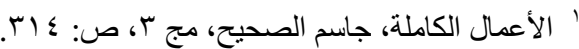

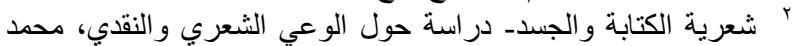

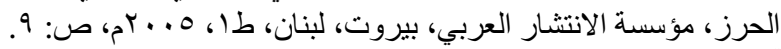

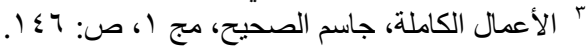


اللغةَ و لا تتحصر فيها، >اولئن كانت اللغة قد استولت على الصورة كأداة للوعي؛ فإن الصورة كانت لها مداخلتها/ مداخلاتها على اللغة كأداة، فعلى قاعدة هذه المداخلة/ المداخلات تمكنت اللغة من التحرك من ملفوظيتها إلى طور مختلف ومغاير، وظائفت و غاياتٍ، وربما وسائل كذلك، إلى الكتابية؛ مفتحة مرحلة وعي جديدة تمامای؛؛ الأمر الذي دفع جوليا كريستيفا إلى الجزم بأنه 》لا يمكن قراءة القول الثعري في كليته الدالة إلا كموقعة مكانية للوحدات الدالة؛ فكل وحدة تمتلك مكانها الدقيق الذي لا يمكن تذويبه في الكل. إن هذا المبدأ الخفي و الفاعل داخل كل نص شعري لا يتمكن من الظهور إلا إذا وعى الأدب بعدم إمكانية اختزاله إلى اللغة الثفويةهُ، وليس الأمر يقف عند حد المثول البصري فحسب، و إنما يتجاوزه إلى فاعليته في اللغوي؛ أي فاعلية الكتابي في الشفوي؛ حيث يتدخل الكتابي في إعادة توزيع المتواليات الصوتية، إما على مستواها القواعدي؛ حيث تتنهك الكتابة بنية الجملة نتيجة ترحيل الخبر من السطر الأول إلى الثاني، ليصبح القول على مستوى السطر الواحد إما مبتدأ لا خبر لله في السطر الأول، وهو معنى مقصود تماما، بوصف

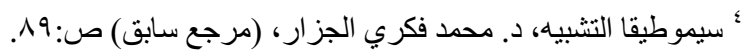

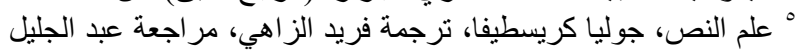

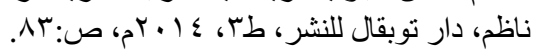

ستتو افق شدة التلقي مع شدة الإرساليةه'، وفي نلك الحالة التي ينتعش فيها الذهن كأثر للمفاجأة يبدأ الشعر يمارس وظيفته الكثفية في بحثه المستمر عن الحقيقة: والثعرٌ ناقذةٌّة تطلّ على الحقيقةِ في حديقتها وما من منزلٍ في الأرضِ للشعراعِ أجمل من قصائدِهمْ ..

هنا، يعمل 》اجاسم|ن على إبراز فعالية الرؤية/الرؤيا في استكناه الحقيقة، ليس بمحض اللغة فحسب، وإنما بتجسيد الرؤية في الواقع الثعري النصي؛ إذ تشتخل الكتابة -وهي عنصر بُتلقى بصريا- في بنية النص، وتشارك في إنتاج الدلالة؛ بل لا يمكن ضمان سلامة إنتاج الدلالة مع غياب الوعي بوظيفتها البنائية؛ لذا فنحن مجبرون على \أن نقر أ بالطريقة التي يكتب بها الكاتب؛ بارث، وهو بعد حداثي ينفي المطابقة الماهوية الحاصلة بين الشعر و اللغة؛ حيث تدخل عناصر غير لغوية (بصرية) في تكوينه؛ فطبيعة الثعر تحتوي

معايير تحليل الأسلوب، ميكائيل ريفاتير، ترجمة وتقديم وتعليقات د.

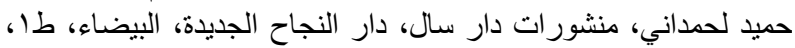

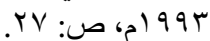

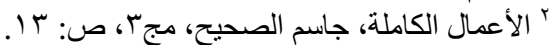

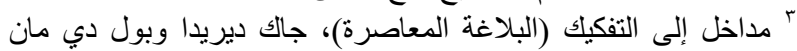

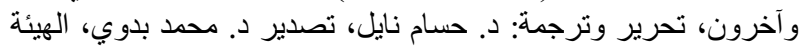

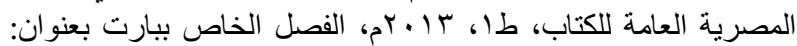

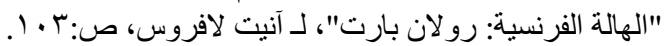


في الاثتنين المتبقيتين، وعلى عكس الترتيب بينهما يأتي الو افر أو لا وحده في السطر الثالث، بينما يأتي الخبب أخيرا وحده في السطر الرابع، ومجموع الأسطر بسجل بقوة تأكيدا على طبيعة الثعر الدائرية، وهو ما تم التأسيس لله بالرسم الذي يجمع المبادئ الماور ائية للشعر سابقا، و التي جلاها إبداعيا هذا النموذج في تحليله الإيقاعي عروضيا. إن امتزاج الأوزان، وإن كان سمة حداثية، فإنه مع ذلك موجود في التراث؛؛ مما يجعل من تفكيك نظام الخليل بوضعه تحت هيمنة الرؤية ليس مجرد ثورة غوغائية على التراث، و إنما استكثاف لطاقاته، وهو ما يعني ضرورة الاسترجاع مرة بعد أخرى من أجل استكثاف المعنى، ويؤكد من ناحية أخرى عدم النفور من الماضي في ذاته، و إنما مما احتمله معه عبر هذا التاريخ الطويل الماتل في القيد و التقليد ؛ لذا فإن العودة أمر طبيعي ما دامت عودة استكثافية، الأمر الذي جعل من الاسترجاع تقنية لازمة لا يمكن إنجاز أية مقاربة إلا من خلالها؛ 〉فأية قصبدة -في الواقع- ممكن فقط إعادة قر اعتها، وليس قر اءتها؛ لأن بعض بناها لا يمكن إدر اكها إلا بصورة استرجاعية، والثعر يفعّل جسد الدال بأكمله، ويجبر الكلمة على العمل بأقصى طاقاتها تحت ضغط

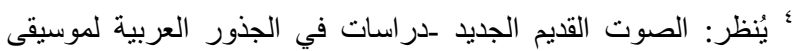

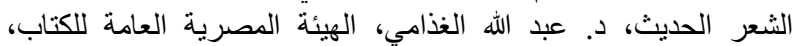
.
الثعر بداية مستمرة'؛ لأن 》البدء نفسه سلسلة من البدايات« ' كما يعبر أدونيس، إلى لا انتهاء، وهو ما عبر عنه جاسم بكون 》الثِِّعرُ طفلُ الروح 《" ، أو خبرا ــو إن كان على مستوى السطر بلا مبتدأ فإنهـ على مستو اه المعجمي (نافذة) استشر افي مفتو ح كذلك إلى لا انتهاء. و إما تتدخل الكتابة في إعادة توزيع المتواليات الصوتية على مستواها الإيقاعي (العروضي) توزيعا يعيد تشكلها من جديد، الأمر الذي يسمح بتفكيك البنية الخليلية سطريا؛ دون حدوث أية نشازات على المستوى الكلي للأسطر، ويسمح في الآن نفسه بامتزاج الأوزان، وهو ما يتضح من التحليل الإيقاعي للنموذج كالتالي:

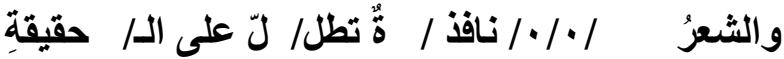

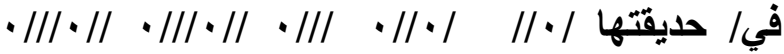
وما من مذ / زلٍ في الأر/ ضِ للشعرا/ ع

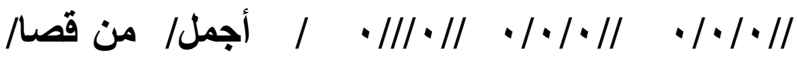

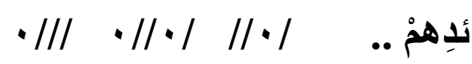
فالسطر الأول يأتي على تفعيلة واحدة مقطوعة من الرجز، بينما يندمج في السطر الثاني نسقان: الخبب في التفعيلات الثلاثة الأول، والوافر ' ' النص القرآني وآفاق الكتابة، أدونيس، دار الآداب، بدون تاريخ، ص:

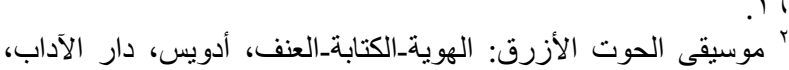

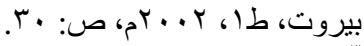

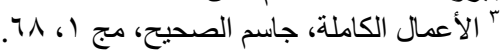


》الثعر|《 إلى طبيعة الثعر الكثفية التي تمتد مد البصر إلى لا انتهاء، في الآن الذي يؤكد حضور دال 》الثعر|《 وحده في السطر فرادتَه؛ فالثعر لا يعبر النهر (المعنى) مرتين، وإنما هو في انفتاح وتجدد مستمرين، دل عليهما الثاعر بصريا تارة بالبياض في السطر الأول من النموذج هنا، والأخير منه بالنقطتين المتتابعتين اللتين تؤكدان لهث الثعراء وراء قصائدهم في ديمومة ارتحال إلى لا قرار؛ إذ إن رؤية الثاعر غير قانعة بضيق المكان؛ لذا تمتد أسفل نحو عمقي لا قرار له: في الثِّبّعر يغدو (الجُبُّ) أوسعَ مدخلا

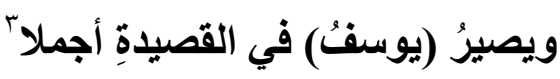
كما ينحو إلى أعلى نحو عالمه (جنته الخضر اء) الأبدي: - (أمي والثعر معراجي إلى أبِيَّةٍة خضر اء بشَّرني بها العَطَّرٌُ ؛ كما يعمل دال البياض في النموذج (والثعر نافذة...)، و الناتج عن التشكيل الكتابي، معادلا بصريا للصمت على الإقرار بحقيقة الثعر فهو ا(يضاعف من كثافة الصفحة، ويجلو لحظات الصمت التي لا تقوى اللغة على تكريسهایٌ؛ ومن ثم فهو انعكاس

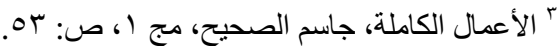

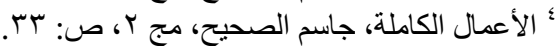

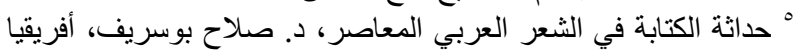

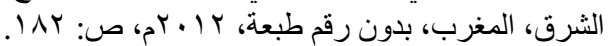

الكلمات المحيطة الثديدة، ويجبر ها بذلك على إطلاق مكنونها الأغنى《'، وهو ما جسده النص السابق؛ حيث إن كل سطر في إيقاعه العروضي المستقل الناتج عن الفاعلية الكتابية لا يمكنه الانتظام إلا من خلال التضام الحاصل بالاسترجاع. والفاعلية الكتابية لا تقتصر فحسب على دخولها في إعادة توزيع المتو اليات الصوتية بما ينتج الدلالة، و إنما ينفرد مثولها البصري بدلالاته الخاصة؛ فمن جهة بصرية خالصة يأتي أطول سطر شعري يملؤه الأسود/ اللغة هو النافذة التي تطل على الحقيقة في حديقتها، الأمر الذي يؤكد أدائية اللغة، في حين يسكن دال 》الثعر ) وحده سطر ا شعريا يتصل فيه مع البياض يسارا، وتتنتغل الحركة الإعرابية (الضمة) -و هي دال اتصال- في تعميق الصلة بين الثعر والبياض، ويمنح البياض حيويته وديناميته؛ >(فالبياض لا يجد معناه وحياته وامتداده إلا في تعالقه مع السواد؛ إذ تفصح الصفحة بوصفها جسدا مرئيا عن لعبة البياض و السو اد بوصفها إيقاعا بصريا يتجه إلى حاسة الإبصار، ويوجد في صنيع الكتابة ذاتها،

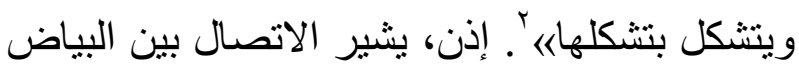
يسار السطر الأول والاتصال بالسو اد الماثل في تيمة

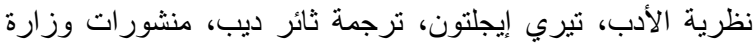

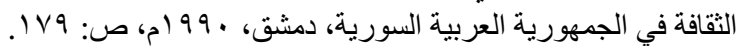

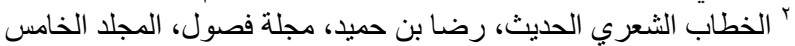
عشر، عدد ب، صنيف 797 (م، ص: 999.
} 
في مساراتها جميعا؛ فيتصل كل دال من الدوال الثلاثة اتصالا مزدوجا، فيكون القول سبب التعب، و انعدام الرؤية نتيجنه، أو انعدام القول (لا أراها تقول) سبب التعب، وانعدام الرؤية (لا أراها +

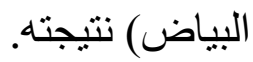

وتوائم الدلالة البصرية لهذا النص مضمونه اللغوي الذي ينواشج مع دال البياض في نموذج (والثُعر نافذة...) في أول السطر، فالنموذج هنا يغمره السواد، الأمر الذي يجسد حقيقة قول القصيدة على الرغم من عدم الإمساك بما تقوله؛ لذا يستكين الثناعر إلى دال 》البياض) بوصفه دالا بصريا ليتمكن من خلاله سد الفجوات التي تتسرب من بين اللغة، وتجعل المعنى غائما، ويواجه به استمرارية السواد أفقا في النموذج (في الثعر يغدو (الجب) أوسع مدخلا)؛ حيث اتساع مساحة الأسود يمنح الثعر معناه الوظيفي التجميعي الذي ظل يؤديه في الثقافة الثفاهية التي لم تغب علاماتها تماما برغم دخول الثعر في صراع مع ثقافة كتابية جديدة، وإن كان اليُحسم دائما في صالح الكتابة أو الثكل المكتوب«"ّ إن الثكل المكتوب هو الذي يجسد الصدت وانعدام الرؤية من خلال البياض والقول والرؤية بالسواد، ويجعل منهما عناصر بنائية

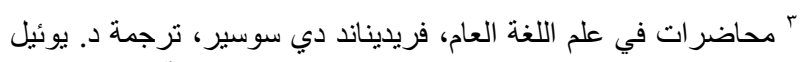

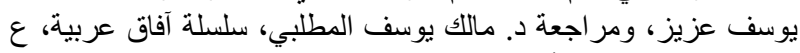

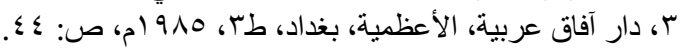

سوريالي على القصيدة حين يقول ما لم تقله اللغة، وسر صوفي حين يسكن اللامقول'، وهو معطى جلي من معطيات المعنى الإبداعي للشعر عند اجاسم

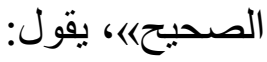
ت تعبثُ من القصيدةِ لا أراها

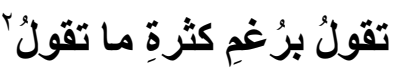
تتموقع الدوال في النص، بفعل الكتابة، حيث تسهم في إنتاج العلاقات بينها كما تظهر في الثكل

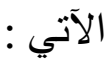

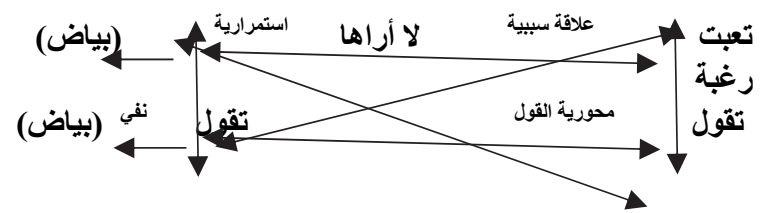

تتصل الدوال ببعضها كما تظهر الترسيمة اتصالا فعّلته الكتابة، فانعدام الرؤية يتصل بدال التعب عن يمينه أول السطر ليؤدي دلالتين متصلتين ومنفصلتين في آن؛ حيث اتصال الدال (تعبت) بوصفه أول السطر مع ما يوازيه في السطر التالي (تقول) يعطي دلالة كون التعب نتيجة قولها الذي لا يراه الثناعر بسبب انفتاح القول على الرؤيا التي توصله بالغموض الذي ينوارى في البياض يسار السطر الأول، والذي يعمل بدوره معادلا بصريا للاال (لا أراها)، وهي علاقة تؤديها خريطة النص

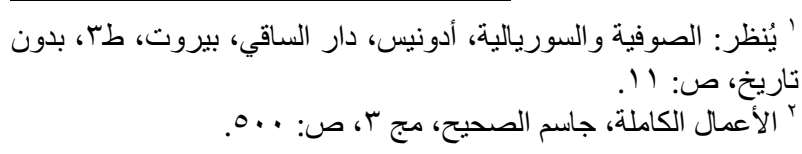


في الثِِّعِ تُطْلِقني النبو وةُ خاطرًا حُرًَا ، بأرديةِ (التَّنَصِ) مُزَمَّلا أمتدُ في المعنى فراسخَ حيرةٍ وأغيبُ في وَجَعِ الحياةِ تَأَمَّلا وأسيلُ بين عبارةٍ وعبارةٍ

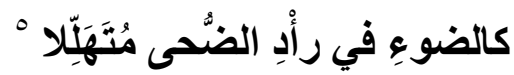
كما تتضافر الدوال (أغيب-حيرة_الضوء) في هذا النموذج مع الدال (صمت) في النموذج الفائت؛ لتحيل جميعا على السر ؛ ليزال على إثر ذلك الثعر 》(سرا في البعيد مؤجلا|خ، والسر كينونة

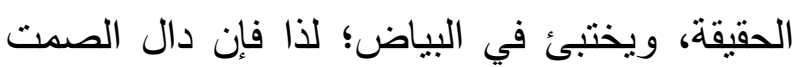
ليس إلا الحقيقة في ذاتها، وهو ما وعته الثعرية الحداثية الممتدة إلى الأساس الصوفي الذي اعتمد كتابة السر نهجا؛ لأنه كلما اتسعت الرؤية ضاقت (العبارة) كما يقول النفري؛ لذا يسيل الثاعر بين عبارة وعبارة؛ فلا يجد (الجب) كدال على العبارة غير الثعر لتوسيع مدخله؛ حيث الثعر (نافذة)؛لذا يتضافر دالّا 》الصدت ـالجب《) معا؛ ليجدا متسعا لهما في الدالين الضدين: الالرؤيا_المعراجي)، وهي كلها دوال نابعة من الأساس الصوفي الذي يعود إليه الثعر أعزلاً عودة حنين إلى الأصل: و(القصيدةُ) أصبحتُ عزلاعَ لا تحمي الحياةَ من الحقيقةٍ ..

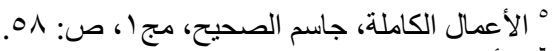

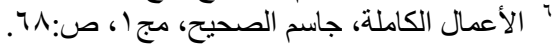

شعرية، وحَكَما في عملية تلقينا له، و إذا كان السواد وجه اللغة، ذلك العنصر العنيق في الثعر، فإن البياض يعد ضروريا من حيث قدرته وحده على أن يسد فجوات ما لم تقله اللغة؛ بل فجوات أنفسنا نحن؛ لأننا 》الا نتعامل مع فراغات بقدر ما نعيشها في أعماق أنفسناه'؛ لذا فإن الثعر بوصفه رؤية يثير العلاقة: ذاتشعر، ويجعل الهيمنة للأخيرة على

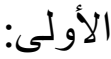

نحن محكومون بالثيّعِر ، وما

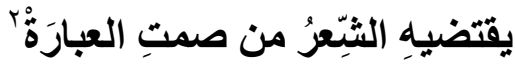
ويتضافر مبدأ الحاكمية مع العلاقة اللغوية: رؤية-رؤيا، ومع الدال (يوسف)، في إنتاج العلاقة:

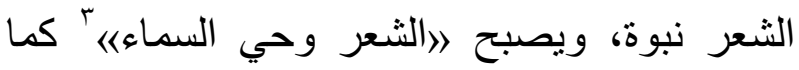
يعبر (اجاسم)، ويصبح 》الثناعر نبيا صعب الفهم، غير مهادن، بطرح داخل حفلة الحياة أسئلة في منتهى الخطورة، قد لا تكون مجدية بالمعيار البراغماتي؛ ولكنها تتبهنا إلى أنفسنا، وإلى أزمة حضور مثل هذه الحفلة. والثاعر لا يتحدث لنا عن حقائق مقررة مسبقا؛ ولكن عن حقائق موجودة في داخلنا، دون امتلاك القدرة على الإمساك بهاه؛'، وهو ما تشكل في وعي 》(جاسم الصحيح《،، وصاغ وفقا له معناه الإبداعي للشعر: - معي

صدع النص وارتحالات المعنى، إبراهيم محمود، مركز الإنماء

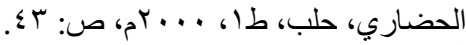

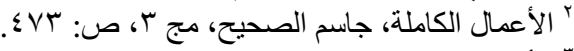

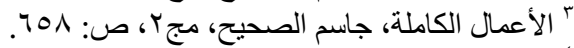

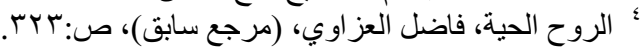


والثعر بوصفه رؤيا راغب في استيعاب

وعاد الثعرُ درويشًا

العالم بكل تضارباته، و استكثاف حقائقه، و استكناه

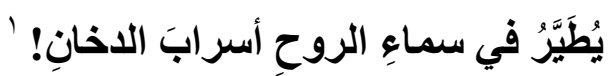
وجوده، الأمر الذي يحتم تعاليه على الانحصار و التحديد، >(فلا يمكن وضع تعريفات نهائية للشعر. إنه ينفلت من كل تحديد؛ ذلك أنه ليس شيئا ثابتا يتناول شيئا ثابتا، و إنما هو حركة مستمرة من الإبداع المستمر. يجيء الشعر من أفق لا ينتهي، ويتجه نحو

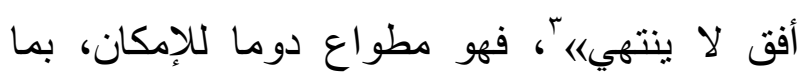

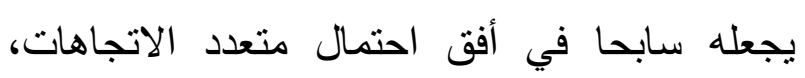

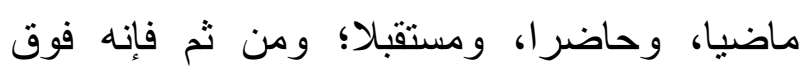
النظرية، ويتجاوزها، ويعمل على الخرق الدائم للقو انين، يتمنع ويهرب وينفر: ياصاحبي .. والثِّعرُ ظبيّي نافرٌ

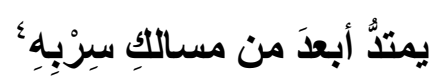
إن النفور ليس من ضيق الزمان المستمر الذي دلت عليه صيغة اسم الفاعل (نافر)؛ فيضعه في لن لهن حيز اللازمان؛ ليكون الثعر هو مطلق الزمن، فهو عودة إلى الماضي لتطهير الحاضر، و واستشراف للمستقبل:

والثِِّعرُ وثبَةُ شَاعرِ من عصرهِ

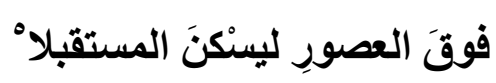

إن مهادنة القصيدة وإهمال تسلحها ليس خوفا من المواجهة؛ لكنه إقرار بالطبيعة القارة فيهما معا: القصيدة والحقيقة؛ فكلاهما سر غيبي لا يطلع عليه إلا بامتلاك قلب صوفي يعيد نظرته إليها من جديد، ويعيش معها في عالم مغلق ومفتوح على إلى

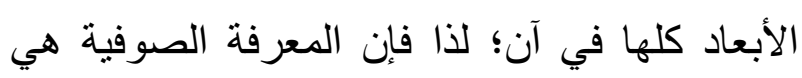
سبيل الثعر نحو استكناه السر: عرفتُ الشعر صوفيَّا

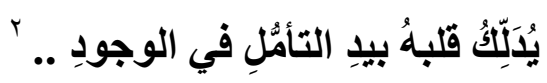
واستدماج الدوال الأربعة: الثعر _الصوفيةــ القلب_الوجود معا في سطرين يدل على كيفيات إنتاج المعرفة الثعرية؛ وفق مبدئها الماورائي الصوفي لدي ذي الفتوحات، كما يشير عنوان الفتوحات المكية

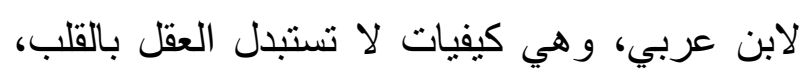

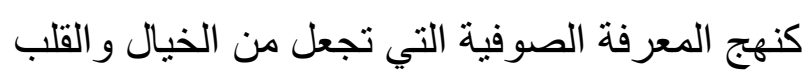
معبر ها الكثفي الذي يمند إلى مالا تستطيع اللغة أن

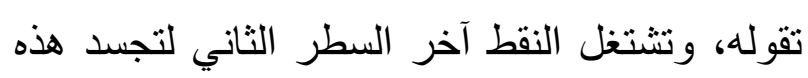
السبحات في عالم اللامرئي عبر وسائل مرئية:

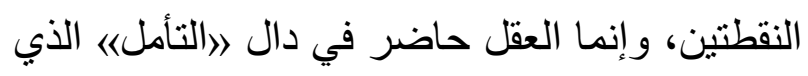
يرتبط بالمخيلة ارتباطه بالعين و القلب في الآن نفسه.

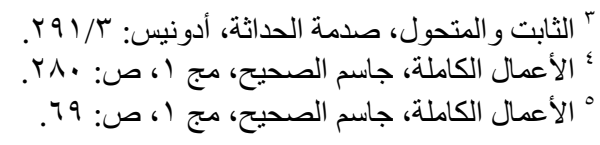

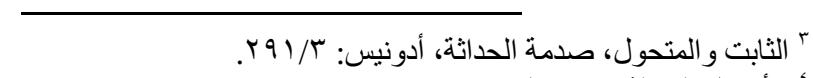

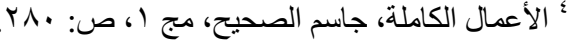

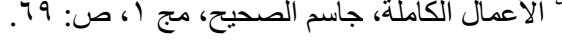


والانفتاح وجه آخر للرؤيا/ الرؤية؛ لأنه يتكئ على البصر بوصفه أهم وسائل الاتصال بالخارج، والاتصال بالخارج صورة من صور الإفاضة عن الداخل، والاتساع عنه، و الثمول؛ لذا فإن الثعر 》ايتجاوز مدى اللغة ويفيض عنها《ْ، كما يعبر ديريدا؛ بل كما يعبر 》جاسم الصحيح) حين رأى القصيدة لا تقول برغم كثرة ما تقول؛ لذا بستدخل الثعر عناصر غير لغوية (بصرية) تشارك في إنتاجه، وتسكنه في منطقة المجاز الذي يستدعي الخيال الذي وإن كان منتجا عقليا فإنه جنس من التصوير كما عبر الجاحظ قديما' : أَبيٌ ظِلِّ أنَتََََّاهُ إذا ضيعتُ أشجارَ المجازاتِ فلا بُدَّ من الثِِّعر إذا . . لا بُدَّ من ظلِّ على الرُّوح ولا بُدَّ من الوردةِ في حقل القتادْ! v إذن، المفارقة حاصلة من كون الثعر مر ادفا جو هريا للمجاز الذي آلته التصوير وبضاعته الخيال، ومع ذلك فهو ليس إلا بحثا في الحقيقة، ليست بوصفها ضدا للمجاز كما هي في المقدمات النظرية والتأسيسات الأولى في الدرس البلاغي، و إنما حصيلته و غايته؛ ذلك أن المجاز أو العدول

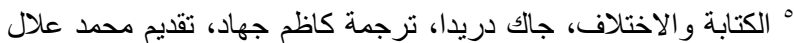

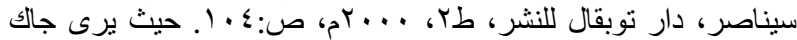

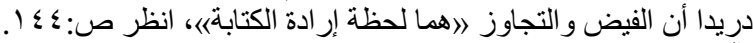

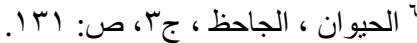

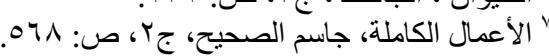

لكنه، أيضا، انفتاح ينفر من ضيق المكان (مسالك) التي يحنشد فيه غيره (سربه)؛ فيتموضع وحده في اللامكان؛ ليكون الثعر هو المكان الوحيد الذي لا ينتمي إلا إلى نفسه: كفاني من عطايا الشعر

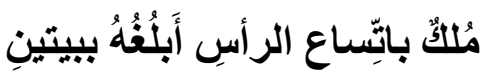
وأحكُمُهُ بقافيةِة وشَطرَينِ إن الشعر لا يسكن إلا حيث الجموح، و الجموح نبعه الخيال، و الخيال إدراك ذهني يشتعل في الرأس؛ لذا يكتفي الشاعر -في قناعة زائفة بفكرة الاكتفاء- بأن يعيش في مملكة الرأس، يسرج جواد الثعر بالأبيات و القو افي؛ ليظلا معا: الثاعر و الثعر غريبين غربة دائمة خارج الحيز زمانا ومكانا؛ حيث

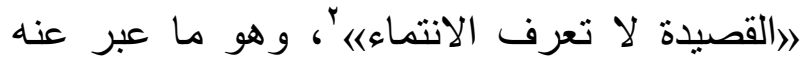
أدونيس بأن \الشعر هو الزمن، وهو بوصفه بداية يبدو كأنه في رحيل دائم عن المكان الذي يقيم فيه، كأنه لا بسكن إلا حيث لا يصل أو لا بستقر «"، وهو ما عناه بأنه الرفض، فالكتابة الثعرية ضد القيد؛ أيا كان شكله؛ لذا فهي لاترفض السائد بنيةً، وطريقةً فهم، وطريقة تعبير و علاقات«؛، وقد ولّد الرفض في الشعر سمة الاختلاف، والاختلاف في ظل الانفتاح يجعل الثعر مركز جذب للحضور و الغياب في آن.

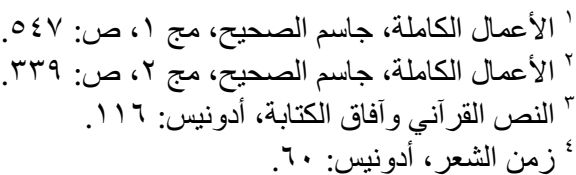


أن نحدد مناطق الغامض و غير اليقيني، من أجل أن نتقن طرح الأسئلة الجديدة. ومن هنا يجب أن نكتب

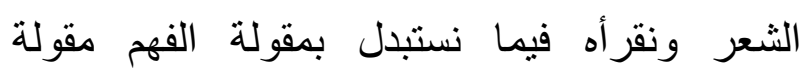

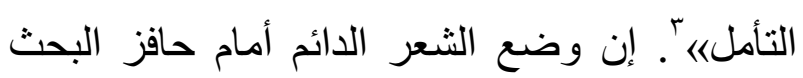

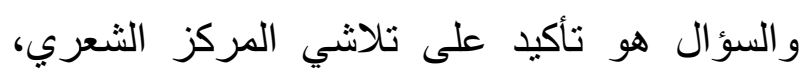

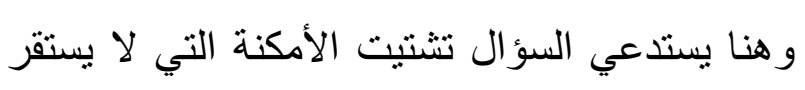

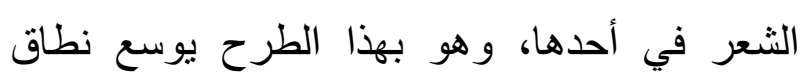
الإبداع والتلقي معا؛ لافبإعطاء النص أكثر من مركز توفر لعملية التلقي وللنص شرطا أساسيا من شروط الإبط الكتابة المبدعة، هو لا نهائية احتمالاتها، وتصبح العملية النقدية، في جوهرها، عملية اكتناه للعلاقات المتشابكة والتفاعلات التي تنتأ من اختيار مركز

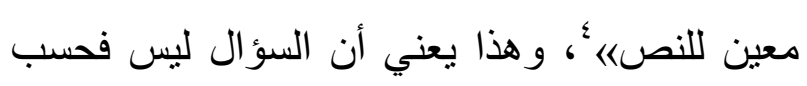

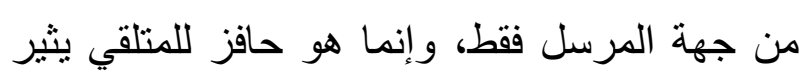

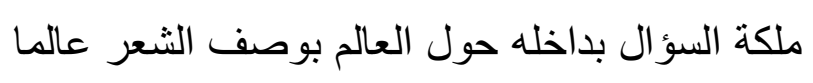

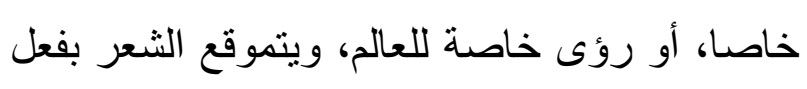

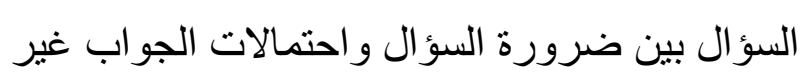
المتناهية؛ مما يفتح الباب واسعا لكل مقاربة؛ |خالسؤال حين يتموضع بين الضرورة والإمكان يحول الخطاب السائر عن مقاصده المحصورة لينع لين بالرضى والقبول، ويباشر مقاربة لها جرأتهاه؛

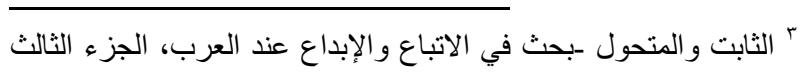

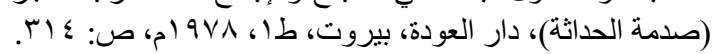

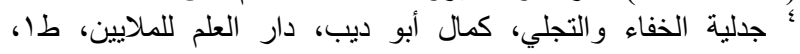

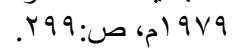

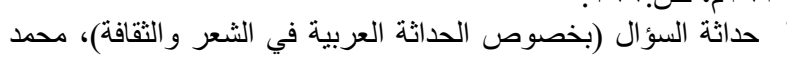

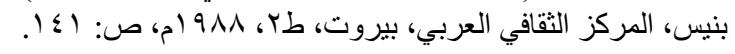

ينتهك قو اعد هذه اللغة التي تستقطبه، ويبحث خارج هذه الاستقطابات، في المكنون و الجوهر: والثِِّّرُ ماهُوَ غير حيرةِ كائنِ

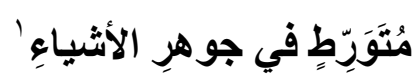

والحيرة كدال لغوي حاضر في القصيدة يجسدها شعريا عدم الانتظام في الأسطر الثعرية داخل نظام الثعر التفعيلي، والمراوحة بين التفعيلي و العمودي في منجز 》جاسم الصحيح《) كله، وهي كذلك باعثة على السؤال الذي هو أداة الفلسفة في بحثها المستمر عن الجوهر والمعنى غير المتناهي، إما حضور ا بلفظ السؤال وأسلوبه:

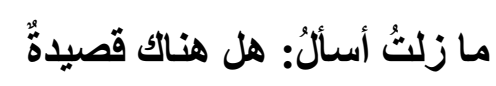

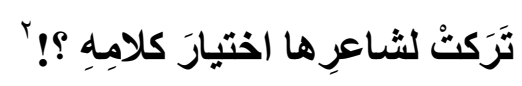
أو عبر بناء الثعر بناء يقتضي السؤال، وفي كلٍ يصبح السؤال متطلبا لانفتاح، والانفتاح داعيا للفئ للسؤال. - الانفتاح سؤال إن انحياز الثعر إلى المعرفة هو انحياز للسؤال بوصفه باب المعرفة، وبما هي المعرفة لا لا تتنهي، فالإقامة عند السؤال دائمة، و الجوابات ليست قطعية؛ لهذا فإن 》القصيدة ليست جوابا؛ بل هي

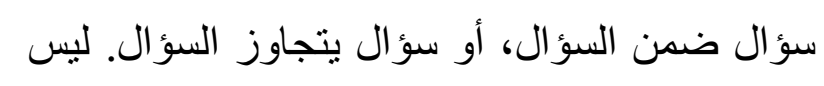

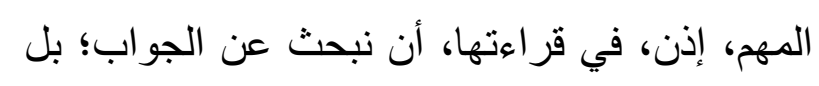


إيضاحية من خلال الولوج الدائم في المتاه و الغموض، وييقى الثعر مع ذلك 》نقيض الوضوح الذي يجعل من القصيدة سطحا بلا عمق، الثعر كذلك نقيض الإبهام الذي يجعل من القصيدة كهفا مغلقاه؛. إن تلك الحالة التوسطية هي التي تجعل الثعر يغامر في المجهول والمختلف والمتناقض، و هو ما سبق أن عبر عنه بشار بانتفاء أن يمتلك قياده شيء أتى به؛ لأنه دائما في لحظة انتظار غائب مجهول غامض لم يأت بعد: فعرجثُ في الإشراقة الكبرى عروجَ قصيدةٍ في الرمزِ نحو حقيقةٍة المعنى لألخخلَ في سديمِ المُبْهَمَاتِ فلم يزلْ يتوَهَُّجُ الإلهامُ بالإبهاجِ

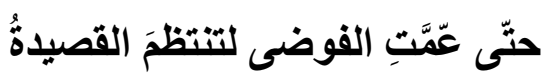

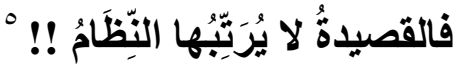
و لأجل هذا الغائب الغائم يصتّعد الثاعر في السماء نحو الإشراقة الكبرى؛ ليتجاوز العالم الأرضي إلى العالم السديمي بوصفه أصل النشأة، وهنالك يواجه الثناعر عالما غامضا مليئا بالمبهمات التي يلقيها الثشاعر إلقاءً في كل جنبات قصيدته؛ مما دعى د. مصطفى ناصف إلى احتساب كل كلمةٍ من

" مقدمة للثعر العربي، أدونيس، دار العودة، بيروت، طז، 9 ام، ص: • الأعمال الكاملة، جاسم الصحيح، مج؟، ص: آ.
ومن أجل هذا كانت استمر ارية السؤال مبدأ ماور ائيا ينظم 》المعنى الإبداعي للشعر عند جاسم الصحيح)؛:

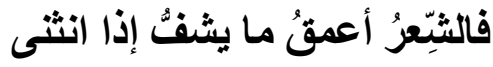
يجلو السؤالَ عن الهوى بسؤالِ فالسؤال لا ييتغي جوابات، و وإنما يولّد سيرورة تساؤلية ليست في مجمو عها غير حلقات في سلسلة الغوض و الأحجية التي يمارسها الثعر : الثِّعرُ أُحجيتِي .. غرستُ جذورَها

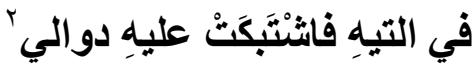
إن هذه الأحجية هي المرادف الناتج عن تشابك الأسئلة وتعقدها؛ مما يجعل من تسلسل الأسئلة متاهة تشتبك فيها الدوال، ويصبح السؤال في ذاته إبهاما، وليس كما هو مألوف استيضاحا للمبهمات. - - السؤال إبهام (غموض) و السؤال بوصفه يتأسس على الإبهام، فهو

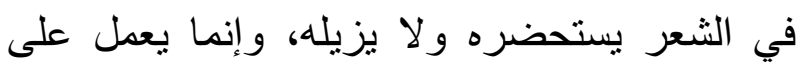
قاعدته، فيأتي المبهم والغامض في الثعر متجسدا من أجل تفجير السؤال الذي هو نتاج الاتساع المعرفي والثقافي و الفلسفي الكامن في ذهن المبدع، و الذي يضاعف من تعقيداته إنتاجا وغموضه تلقياّ؛ ومن ثم يصبحان معا: السؤال و الإبهام، سمة متمكنة في الثعر الذي يسعى نحو غايات ومهمات كثفية

\footnotetext{
الأعمال الكاملة، جاسم الصحيح، مجّ، ص:0V.

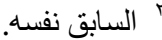

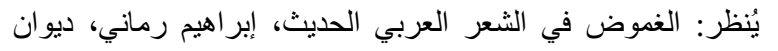

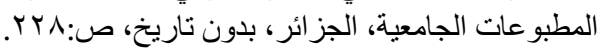


انتباك دواله، وتعدد وتنوع وتوالج المبادئ الماور ائية له، ثم في تجاوزه عن مدى اللغة تجاوزا مثلته الكتابة كثريك إبداعي لا يمكن إهماله، والتي تتجلى أبسط ما تتجلى في لعبة الأبيض والأسود و التشكيل الكتابي على الصفحة الثعرية، وهو و اضح في هذا النموذج الثعري، كما هو واضح في كثير من النماذج الأخرى، إما من جهة اتصال نهايات الأسطر بما يعادلها بصريا (البياض) بما يمكن تمثيله رياضيا كالآتي:

$$
\text { القائهين = البياضة = البياض. }
$$

وتجتمع كلها في المسألة المنطقية: القصيدة + تائهين+ الطريق+ الفناء = البياض. القصيدة + تائهين+ الطريق+ الفناء = الثعر. إذن: البياض = الثعر، وهو ما يعطي دلالة انفتاح الأمكنة جميعا في الثعر الذي لا يستقر في أحدها برغم كونه لا يوجد إلا في موقعة مكانية بوصف البياض هو التجلي البصري للصفحة، كما يعطي دلالة الجوابات التي لم ـولن- توجد؛ ليبقى الثعر سؤالا أبديا، ودلالة النبوة بوصف البياض علامة عليها، ثم المتاهة بوصف اللون الأبيض يشتت البصرٌ. و إما من جهة المتاهة التي يجليها

• ينظر: التفكير بالعين، سعيد العفاسي، دار الوطن للصحافة والطباعة

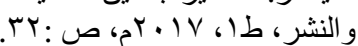

النص رمزا'، و الرمزية ليست هنا بمعناها السيميائي القائم على العرف الاجتماعيگ؛ و إنما بمعناها التخييلي الإيحائي، أو بمعناها الصوفي -خصوصا مع حضور مصاحبة الدال (عرجت) الذي يحيل على معارج ابن عربي- حيث 》الصوفية تفهم مظاهر العالم انطلاقا من كونها رموزا لحقائق لا مرئيةه؛ ، وهو ما يعني كون الأشياء نفسها رموزا، والثعر بوصفه يستدعي الأشياء وينقلها إلى عالمه، فهو بذلك رمزي منلها. ومع هذا الغموض فالثاعر أكثر اقترابا من مصدر الإلهام، و أكثر شمو لا و اتساعا في الرؤية؛ ليرى من حيث يقف في غير النظام العالمَ منتظما وجميلا (شعريا).

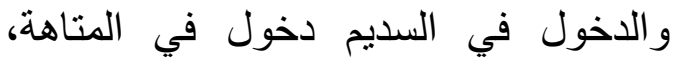
و المتاهة عتبة الغموض والأسرار؛ لذا فإن الثي الثعر متاهة عند اجاسم الصحيح)؛

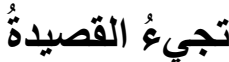
في رَبِ رحَّالةِ تائهِينَ

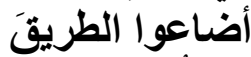

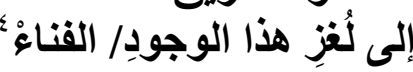

ومتاهة الثعر تتجسد في خارطته البنائية من جهة كما فات في التحليل العروضي، وتتجسد كذلك في

لينظر: نظرية المعنى في النقد العربي، د. مصطفى ناصف، دار الأندلس

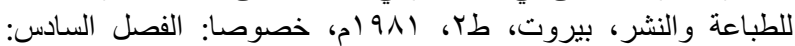

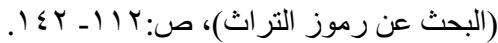

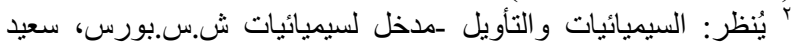

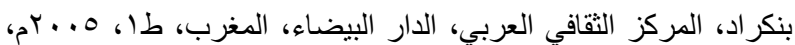

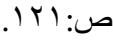
' الإبهام في شعر الداثة العوامل والمظاهر وآليات التأويل، د.

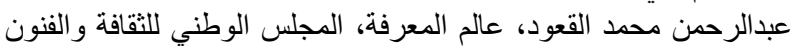

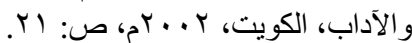

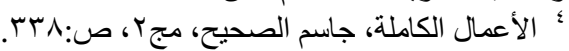


الخمسة المشكلة لنموذجه التو اصلي، وهو أمر نشكك فيه؛ حيث إن الوظيفة الثعرية للغة ليست إلا نتاجا للصراع بين هذه العناصر جميعا، دون نفي دخول الرسالة بخصائصها النوعية و عناصر ها التكوينية في هذا الصراع، وقد صرّح بذللك د. محمد العمري بشيء أقل حدة من تشكيكنا النازع إلى المساواة التقريبية بين الوظائف، وجعل الوظيفة الثعرية نتيجة للصر اع بينها؛ حيث يقول: \الوظيفة الشعرية لا تلغي الوظائف الأخرى؛ بل تكتفي بالهيمنة عليهاه؛ ، ويعطي ذلك نتيجتين: - دخول مبدأ القصدية في إنتاج شعرية الرسالة، حيث تشتخل الوظيفة الانفعالية التأثيرية للمرسل في إنتاجها؛ مما يجعل تتبع التيمة 》الثعر) موضو عيا

بحثا وظبفيا.

- دخول الرسالة (القصيدة) بذاتها في عملية الصراع مع مبدأ القصدية، إثباتا أو نفيا، بالإضـافة مع دخولها مع بقية العناصر الأخرى في النموذج التو اصلي. وتسلم هاتان النتيجتان إلى فعالية البحث في الوظائف من أجل استكثاف 》المعنى الإبداعي للثعر عند جاسم الصحيح/، ويمكن تقسيم الوظائف إلى قائمنتين:

- م وظائف بنائية.

$$
\text { - وظائف اجتماعية. }
$$

؛ البلاغة بين التخييل و التداول، د. محمد العمري: V9.
الخط المتعرج الذي رسمه عدم انتظام الأسطر كما هو موضح بجانب النموذج. إن هذه المبادئ الأربعة تمثل السنن الذي تُحاك القصيدة على منواله، وهي كلها فاعل ومفعول، موصِل وموصنلّ إليه في آن؛ حيث تعمل معا في المزيج الثعري، وتنبثق منها سلسلة الوظائف التي يمارسها الثعر، وتمثل الثق الثاني من معناه الإبداعي. ץ - الوظائف

تختلف المقاربة الوظيفية عن الوصفيات اللسانية في كون الأخيرة تبحث في البنى المجردة في ذاتها، دون أي التفات إلى ما تستعمل من أجله، بينما الوظيفة ترتبط بالغاية و الغرض'، ثم بالنسق الذي تستعمل فيه؛ مما يجعل من دراسة الثعر دراسة وظيفية أمرا ضروريا. وما دام مبدأ رؤيا العالم هو أساس العمل الإبداعي ومعناه، فإن المعنى الإبداعي -وفقا لما يقرره غولدمان بإن >اكل رؤية للعالم لها طابع وظيفي《״ - لا يمكن تصوره تصور ا كاملا مع تغييب ناحيته الوظيفية و إهدار قيمها في تشكيله. ولقد حدد جاكبسون للرسالة في نموذجه التو اصلي وظيفة شعرية، ومنحها الهيمنة على بقية الوظائفَّ، غير أن الهيمنة تعني تغليب الرسالة على بقية العناصر

ينظر: المنحى الوظيفي في الفكر اللغوي العربي ـالأصول والامتداد،

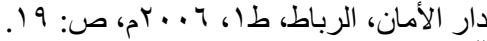

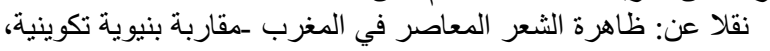

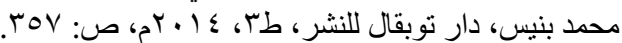

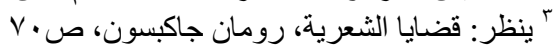


سبق الإصرار'، وهو ما عناه 》جاسم الصحيح|خ

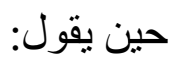

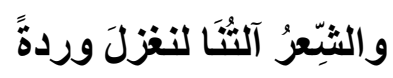
في حقل وحشتينا، ونرسمَ بلبلاء

فتعدد الوظائف الآلية بين الصناعة (نغزلية) و الزر اعة (حقل) و الاجتماع (وحشتنا) و الفن (نرسم) والجمال (وردة-بلبلا)، يؤكد من جهة أولى الأثر الإنساني في الثعر ، ومن جهة ثانية تعدد وظائفه، ثم رهن من جهة ثالثة تعدد الخامات التي تتشكل منها المادة الثعرية، والتي هي اللغة، وما يخرج عنها في آن أن.

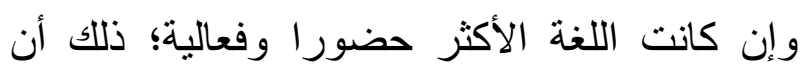

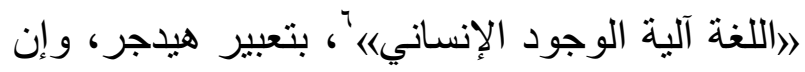

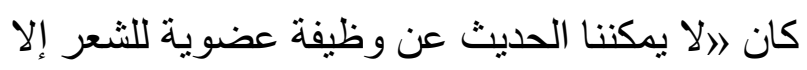

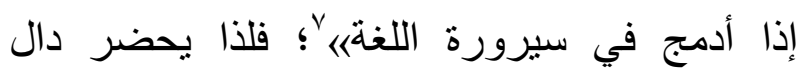
》اللغةة《 في منجز 》جاسم) ليحمل عبأه في تشكيل

$$
\text { المعنى الإبداعي لديه، يقول: }
$$

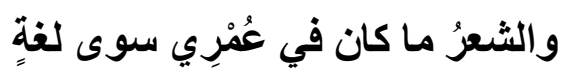

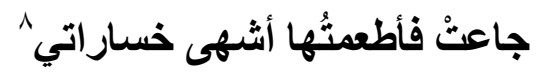

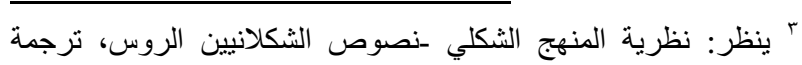

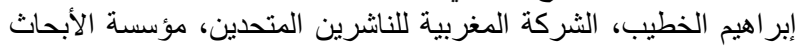

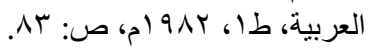

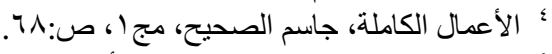

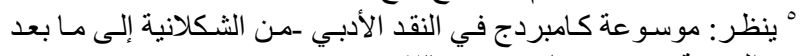

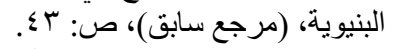

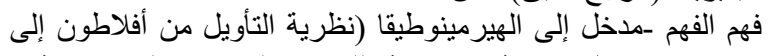

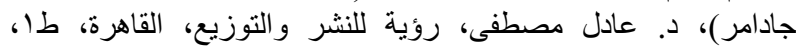
rov

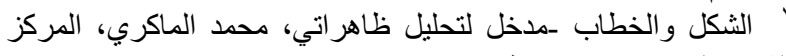

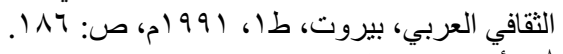

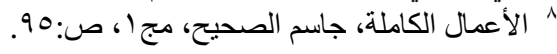

أ الوظائف البنائية

تعني الوظائف البنائية تلك التي تختص بالمعنى الثعري من خلال بنية القصيدة نفسها، و الأمر هنا خاضع للمقاربة الموضو عية للار اسة من من لهن ناحية شكلها كما أوضحت في أولها؛ ومن ثم فإن

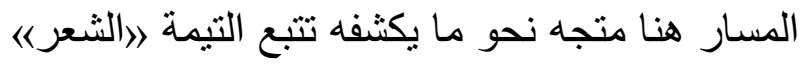
من وظائف بنائية يحتملها رالمعنى الإبداعي للشعر عند جاسم الصحيح)، هو هي: تعني الآلة في النظرية الثكلية عند جماعة الأوبوجاز، في دراستهم قوانين الإنتاج الأدبي، لهابه 》عودة إلى الحِرفية)《 كما يزعم شكلوفسكي، وتولَّد عن ذلك منهج يدعى الثكلية الآلية'. وقد أدى مبدأ التماثل مع الآلة وظيفة التركيز على المادة المتعينة نفسها (النص الثعري)، بعد أن اختزلت الألعمال الأدبية في الإنسان، وليس معنى هذا إلغاء وجوده بالكلية، و إنما الآلة هي النتاج لنشاط إنساني مقصود تقوم فيه مهارة محددة بتحويل المادة الخام إلى آلية مركبة تلائم غرضا معيناه'، غير أن مفهوم الآلية

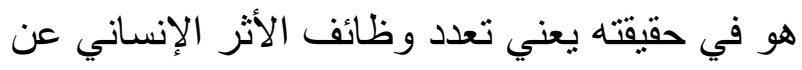

\footnotetext{
ينظر: موسو عة كامبردج في النقد الأدبي -من الثكلانية إلى مـا بعد المدان

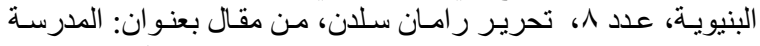

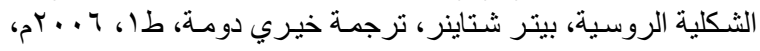

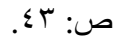

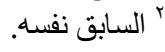


إن اقتصار الثعر على اللغة ليس إلا اجاسم《 أن المعنى الثعري هو ذلك المعنى البعيد، بوصفها أكثر عناصره البنائية حضور ا، وإن كان لا ل يقول:

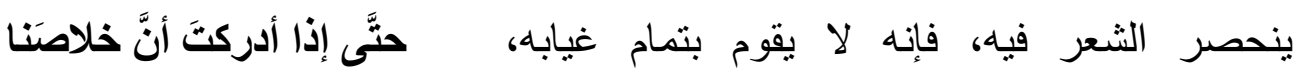

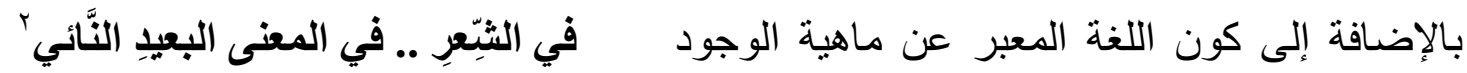
وأول درجات تلمس المعنى البعيد هي لئي المجاز، و هو في حقيقته شكل من أثكال ضيق اللغة عن المعاني أولا، ونتيجة للعلاقات التي يفرضها نظام الثعر ثانيا؛ حيث إن تمايز أنظمة العناصر المكونة للثعر تعمل على إنتاج المجاز ات التي يعبر بها الثناعر محنة توفيق هذا التمايز من ناحية، و إنتاج معناه الثعري من جهة ثانية، يقول:

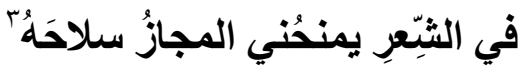

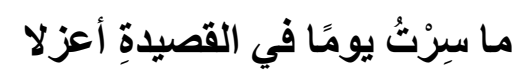
والمجاز شقيق التجاوز، والتجاوز مكمن الثعرية التي تتلمس المعاني البعيدة الضمنية، ويجعل القصيدة قادرة على احتواء المتناقضات، إما من جهة عناصرها البنائية، أو من جهة احتوائها للعالم المتضارب بوصفها رؤية له. - الثعر هيمنة

منح جاكبسون الوظيفة الثعرية للرسالة الهيمنة على بقية عناصر نموذجه التواصلي؛، وهو هونه ما يعني انحياز الثناعر للفاعلية الإبداعية، من أجل تحقيق فر ادته، تلك الفعالية تمارس وطأتها وهيمنتها

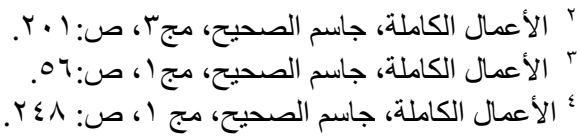
الإنساني؛ \فاللغة لا تعني شيئا خارج حرية الاختيار

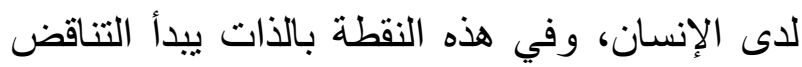
بين إسكان اللغة في قوالب ضمنية هي في الواقع فكرة مسبقة لنظام علاماتي قياسي مبسط إلى حد المثالية، وبين لغة الوجود التي يمارس بها الإنسان الحوار مع غيره من الناس، وينطق العالم، وينطق

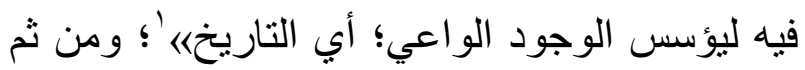
تصبح اللغة رمز حرية الثناعر وذاتيته، واجتماعية الثعر و علاماتيته، وصراع النظام والانتظام، أو الألفة وكسرها؛ لذا اعتنى الثكلانيون ببنية اللغة الثُعرية التي أسلمتهم إلى تتبع السلم الوظيفي للثعر؛ حيث لا تتأسس اللغة الثعرية إلا على وظيفتها الانزياحية، بصرف النظر عن الاختلاف في تصور الانزياح بين الثكلانيين أنفسهم، لاسيما جان كوهين الاحين

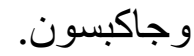
- - الشعر انزياح: و اللغة الثعرية لا تتحقق إلا بالانزياح، أو ما عناه عبد القاهر قديما في نظرية النظم بالعدول الذي لا يستهدف الثاعر من خلاله المعاني المبانرة، و إنما المعاني الثواني البعيدة والضمنية؛ لذا يرى

\footnotetext{
وجود النص الأدبي/ نص الوجود، مصطفى الكيلاني، مجلة الفكر بهرب

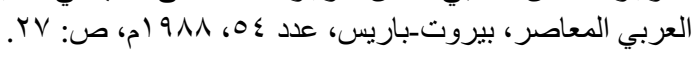


معا بيت لا ريب فيه، فإذا كانت التوقعات الثعرية تتنبأ بأسلوبية الثاعر الدائمة في خروجه على التقليد، وكسره الأبدي للنظام، فإن عودته إلى النظام التقليدي هو الذي مكنه من كسر الألفة بالجديد، وانتهالك نوقع استمرارية الخروج على نظام الخليل العمودي. ويؤكد من ناحية جدارة التراث؛ لذا فإن العودة أمر طبيعي، وتطرح إذن البنائية التقليدية للشاهد هنا نهجا من طبيعة الثعر المستعصية على القراءة الوحيدة والأولية في الممارسة النقدية، وهو ما أسس له مبدأ الرؤية/ الرؤيا كما فات. كما تطرح أيضا هيمنة الوظيفة الماور ائية على الرسالة الشعرية، وانتقالها من القاع كمادة خام دأب الثاعر على إعادة تشكيلها وفقا لرؤياه إلى السطح حاملة سمة الشعرية لا التقليد. إن الثعر لا يتحقق معناه الإبداعي إلا عبر ثنائية الهدم والبناء، هدم المألوف واستعادة بنائه وتوزيعه منتظما من جديد؛ لأن الانتظام شرط المعرفة؛ ومن ثم شرط الأدبية؛ لذا كان البحث في الأدبية/ المعنى الإبداعي شخل نظرية الأدب، و \الكي يكون أي نظام كلامي صالحا لحمل ونقل المعلومة ينبغي أن يكون بالأساس نظاما، بمعنى أن لا يتكون من عناصر عشوائية؛ بل يتحتم أن يكون كل عنصر في هذا النظام ذا علاقة عضوية ببقية العناصر، بحيث يمكن أن ير هص به نوعا من الإرهاص. غير أن هذه العلاقة القائمة بين هذه العناصر لا ينبغي أن تكون علاقة أوتوماتيكية تماما؛ لأن كل عنصر بنائي
على المبدع نفسه؛ ليظل للشعر وحده القول

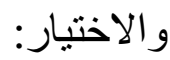
ما زلتُ أسألْ: هل هناكَ قصيدةٌ تَرَكتُ لشَاعرِها اختيارَ كلامِهِ ؟؟! يصرّح 》اجاسم الصحيح) بهيمنة القصيدة على المبدع؛ مما يجعل مفهوم القصدية محل ارتياب؛ لكنه ارتياب زائل ما دام ينحاز إلى الثعر والإبداع؛ حيث تكون القصبدة امتدادا للقصدية، وربما مساهمة في تشكيلها، الأمر الذي يجعل من مقاربة التيمة 》الثعر|" موضوعيا فحسب دون الالتفات إلى . مساءلتها عبر المنجز الإبداعي نفسه تفريغا لمحتواها. إنه إذا كان الانزياح يمثل ماهية العمل الإبداعي ويمنح الثعر وظيفته الأولى التي حددها له جاكبسون، فإن الانزياح الدائم عن النموذج القانوني التقليدي يحوله بالضرورة إلى نمط؛ مما يوقعه في هوة التوقع والألفة التي ربما تخرجه من نطاق الأدبية؛ لذا يعود الثاعر إلى النموذج التقليدي كما هو؛ باعتبار أن \الانتظام الواقع في القصيدة قد يكون نفسه انتهاكا للتوقعات الثعريةهاء، و هو الأمر الذي جسدته الممارسة التطبيقية في الثاهد هنا؛ حيث بناه الثاعر موافقا لسيمثرية القالب التقليدي لنموذج الكامل، ثناثة تفعيلات من (متفاعلن) وتتو عاتها في كل سطر، وكل سطر يمثل شطر ا تقليديا، وكلاهما

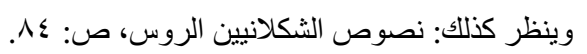

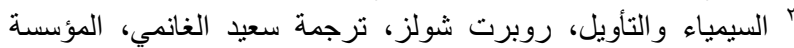

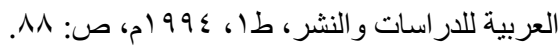


الأخذ والتضمين والاقتباس، وإنما دخوله في جدلية فكرية ترفده بالغموض، وتوسع من مدى النص، وتفتحه على الجهات كلها، فيتعالى من خلال وجهه التداخلي بين الأجناسي على مفهوم \النقاء النوعي|، ويصبح على إثر ذلك سيرورة من التحولات، الأمر الذي يؤكده ارتباط ظهور التناص كمصطلح مع التحليلات التحويلية عند جوليا كريستيفا؛؛ حيث اعتبرت التناص سمة بنائية للنصوص، وفي مقدمتها الشعر، و هو ما صرّ ح به جاسم الصحيح في تشكيله للمعنى الإبداعي للتيمة 》الشعر| حين أورد المصطلح بذاته في منجزه الإبداعي، و اضعا إياه بين قوسين للفت البصر إليه، يقول:

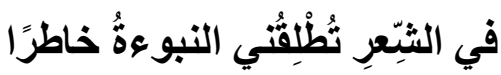

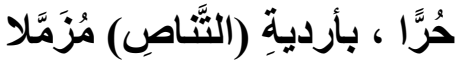
أمتاٌُ في المعنى فراستخ حيرةٍ وأغيبُ في وَجَعِ الحياةِ تَأَمُّلا وأسيل بين عبارةٍ وعبارةٍ

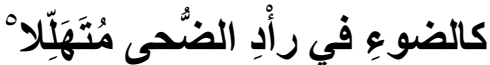

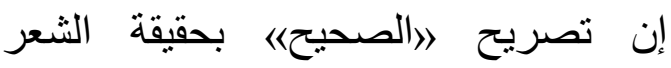

التناصية يحمل في قراره علاقة الثعر بالتراث، فبما هو التناص \حدوث علاقة تفاعلية بين نص سابق ونص حاضر «" فإنه في الآن نفسه بريد التراث إلى

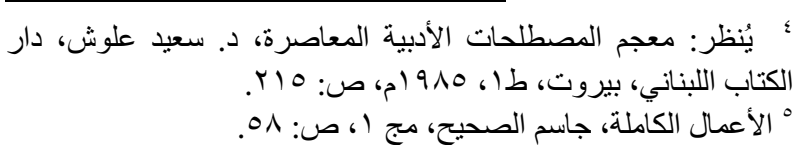

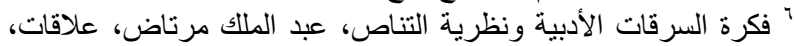

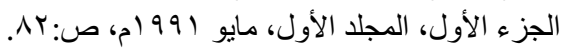

إذا أوحى بتاليه إيحاء محدد الدلالة؛ فإن توصيل أية معلومة جديدة في ظل هذا النظام يغدو أمرا غير ممكنه'. . واشتراط عدم الإيحاء المباشر الأحادي الدلالة والنظام هو وثبة نحو المغايرة و المفاجأة التي تحقق للشعر ومضته و إثر اقه، وحينئذ يشتخل الشعر من جهة في إثارة القارئ؛ ومن ثم يتفاعل مع النص، بحيث يكتب النص قارئه أو يكتبه قارئه، هذه المشاركة هي أحد أهم النقلات التي أحدثثها الحداثة في الممارسة الإبداعية، وتسربت في تشكيل 》المعنى الإبداعي للشعر عن جاسم الصحيح/، بحيث لم يكن النص حبيس قلم كاتبه، ثم هي من جهة أخرى تفتح آفاق التأويل واستثمار التقافات التي هي لدى القارىئ و الثـاعر معا. - - مالشعر تناص: (علاقات) تسلم الطبيعة الوظيفية للثعرية، من حيث هيمنتها، إلى حقيقة كون الثعر علاقات متبادلة في نظامَّ، و إذا كان الشعر يتأسس على المبدأ الرؤيوي الانفتاحي الذي تغذوه الثقافات، و إذا كان يمثل في وجوده علامات ذات تر اكمات تداولية وثقافية قارة في ذاكرتها، و إذا كان كذلك لا يُتلقى إلا نصيا جامعا، كما يسميه جينيت '، فإن كل ذلك يؤكد طبيعة الشعر التناصية، ليس بأن يتحدد مفهومه ضمن منظومة

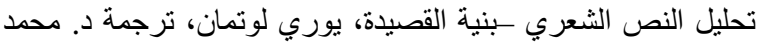

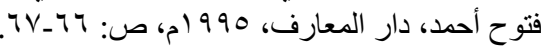

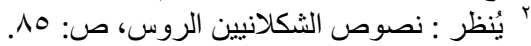

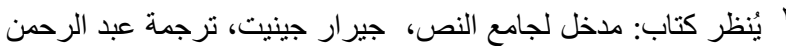

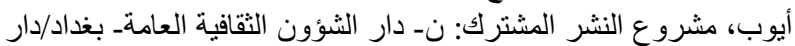

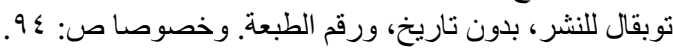


شعر جاسم على مستويين: الأول تتاص بنائي اتخذ

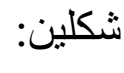

- تناص مع القالب العمودي، كما يتجلى في

$$
\text { النموذج السابق. }
$$

- تناص مع المادة الخام للعروضية الخليلية التي لم يخرج عنها الثاعر، وإن أعاد توزيعها وفقا لرؤياه، بوصف التناص

$$
\text { علاقة، وليس تقيدا بالسابق. }
$$

و المستوى الثاني في حضور التناص حقيقة بين شعر جاسم وشعر أدونيس، على سبيل المثال، وهو ما يمكن تمثيله بالعلاقة التشبيهية: الثعر طفل ب -

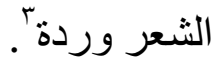

وبوصف التناص في أساسه علاقة/ علاقات،

فإن الثـاعر يستثمر دال 》الجسد《) كتتويع وإلماح على مثل هذه العلاقات، من أجل فتحها على مجالات أخرى غير ما يحتمله مصطلح التناص، خصوصا أن كليهما مرتبط بإنتاجية المعنى، فكما برى ميرلو بنتي في في فلسفته الظاهر اتية أن \المعنى لا يمكن عزوه لشيء إلا من خلال الجسدی"، وهو ما يعني

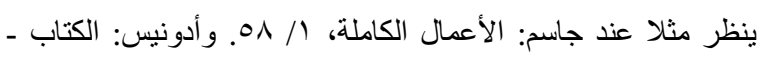

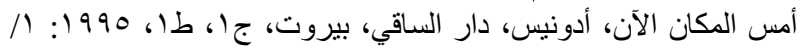


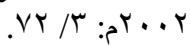

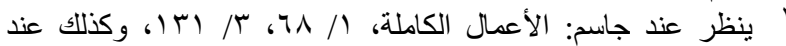

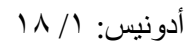
" موسوعة النظرية الثقافيةـ المفاهيم والمصطلحات الأساسية، (مرجع

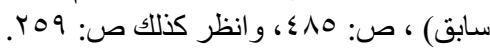

الحاضر، وهنا يثير المعنى الإبداعي للشعر عن 》اجاسم الصحيح《) إثكالا جدليا انبثقت منه كبرى قضايا النقد العربي الماتلة في قضية القدماء والمحدثين. ويكثف نص 》الصحيح《) عن رؤيته الحداثية إلى التراث، إنها ليست تقوقعا فيه، و إنما تجاوز له، يحضر التراث حضور الفعل لا حضور المنتج، حيث يؤثر التناص بنائيا، إما في المتناص (الحاضر)، أو المتناص منه (السابق)، وفي الحالين لا يبقى المتناص منه كما هو، وهي الوجهة التي قبلتها الحداثة للتراث؛ هي ا(تنظر إلى التراث باعتباره فعلا معرفيا، وليس مجرد نتاج معرفي، والفرق بين الاثنين جد شاسع، والبون بينهما جد كبير؛ فالنتاج أيا كانت صفته- يحمل ضمنا دلالات كونه منجزا مكتملا ومنتهيا كيفما تم إنجازه، وكما تيسر اكتماله و إنهاؤه؛ ومن ثم فلا يمكن تلافي أوجه قصوره ومظاهر الخطأ فيه، و على هذا فلا مجال إلا للتعصب لله أو التمرد عليه، وكلا الموقفين خطأ وخطر، ليس عليه فحسب؛ بل على الهوية التي يقوم بأكبر قدر من خصائصها. أما النظرة إلى التراث باعتباره فعلا معرفيا، فهو -وإن كان مع كونه منجز ا- ضد اكتماله في كل لحظة، وليست ماضويته أكثر من طور من أطواره، ومرحلة من مراحله، ولحظة من عمر ذهابه إلى المستقبل؛ استشر افا لهذا الاكتمال الذي لا يكتملی' . وقد تجلى التناص في سيموطيقا التثبيه، د. محمد فكري الجزار، ص: 11 1. 
أكانت علاقة متحققة فعلا، أم ممكنة التحقق، أم متخيلة. إن الجسد بمثابة قابلية لا مشروطة ولا متتاهية لأية علاقة، أو لنقل: إنه انفتاح شهو اني على العالم (الفيزيقي أو الميتافيزيقي) بحثا عن علاقة/ علاقات ما تحقق له بديلا وجوديا كفئا من قوة المعنى الأول القائم في عالم الإرادة فيستند إلى كينونتهی'. والجسد بوصفه وجود الذات المادي (تجسدها) جزء من (المعنى الإبداعي للشعر عند جاسم الصحيح/)،

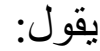

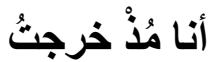

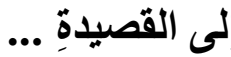

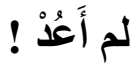
مازلتُ خلفتَ الروح أتبِعُها فضَنَيَّنَي مدى روحي وضيَّعتُ الطريقَ إلى الجسدْ يقع دال 》الجسد《 موازيا أو معادلا موضو عيا لدال (القصيدة|)؛ فثمة تلاحم حميمي بين الثـاعر و القصيدة يسمح له بالبحث عن ذاته بشقيها الروح والجسد فيها، وبما هي القصبدة متاهة، فانن تلمس معالم الجسد يبدو مستحيلا، ويستحيل أمر البحث عن الذات ضربا من الشطط في ظل مغريات المادة التي تطمس العالم، ويصبح المعنى الإبداعي

من مقدمة أ. د. محمد فكري الجزار لكتاب: شعرية الجسد ـدر اسة نقدية

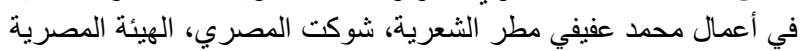

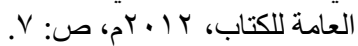

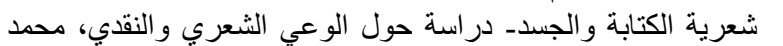

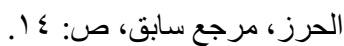

الأول: ارتباط دال الجسد بالمعنى الإبداعي

للشعر بوصفه علاقة (تناص). الثاني: ارتباط دال الجسد بالمعنى الإبداعي

للشعر بوصفه أداة.

إن تحول الثعر من الثفاهية إلى ثقافة كتابية

هو إقرار بموقع دال 》الجسد《) منه؛ إذ لا يمكن أن يتلقى الثعر إلا بوصفه جسدا و عبر خارطته، الأمر الذي يجعل من اعتبار الموقعة المكانية جزءا من ماهية الثعر مقبو لا؛ بل ضروريا. إذن، يمثل دال 》الجسد《) علامة ماهوية شعرية؛ فهو من ناحية يعني وجود الذات، تلك التي كانت نقطة ارتكاز الشعر على طول تاريخه، بدءا من غنائيته، حتى حداثته، ومن ناحية أخرى يحمل معاني الثههوة و الانتهاك و العذرية معا، وما دام يعني الذات؛ فهو يعني نوعا من العلاقة بالعالم التي تؤسس لوجود العالم نفسه، و واستخلاصه ـ ـعبر الرؤية/ الرؤيا- من زحام مفرداته وموضو عاته ومفاهيمه، وهو بذلك -دال الجسد- تنوع على مبدأ الرؤية/ الرؤيا، بوصف الأولى عنصر ا حسيا يسهم الجسد في إنجازه، وهي لا تتحقق وحدها، ورإنما كينونتها مشروطة بعلاقة اتجاهية، والعلاقة ـأيا كان نوعهاتحمل في درجتها الصفرية دلالة النسبة في الآن نفسه الذي تعني فيه التمايز والاختلاف؛ لذا فإن 〉الجسد قائم في حسيته يحاول أن يحقق نسبة ما في عالمه؛ وبالتالي فهو مفتوح على العلاقة ضرورةًا 
الثعرية- تسمح له بالانتقال من مجموعة الوظائف الاجتماعية إلى الوظائف البنائية، أو المراوحة بينهما، فالجسد في الثقافة الإنسانية بعامة تجلَّى مستورا، الأمر الذي جعل من انزياحه عن طبيعته التي خُلق عليها دالا شعريا بامتياز، وأصبح النص الشعري في وظيفته الكثفية جسدا؛ لذا فإن ا(ثثثلات الجسد/ النص المجازية والاستعارية بوصفها مرجعا يؤسس لثعرية اللغة ليست سوى تمثنات تستجيب للتجربة الحياتية اليومية للذات الثـاعرة، وهي تجربة تختزن في داخلها نمطية الإدراك و التفكير، و عبر هذه الاستجابة يحدث نوع من الانزياح الجسدي، فيرتحل من خارج اللغة إلى داخلها؛ أي يتحول من الجسد/ الوجود إلى الجسد/ المفهوم، الأمر الذي يكثف عن وجود جسد شعري يحمل سمات النص نفسه بحيث يقطع صلته بالجسد الخارجي؛ ولكن الوشائج تظل قائمة؛ إذ تشكل علاقة جدلية تراسلية مفتوحة تغذي الواحدة الأخرى《ّ. و الستر ضد العلاقة، أو إخفاء لها؛ إنه خباء واعتز ال لا يواءم طبيعة الثعر، وترتب على كثف الستر حتمية العلاقة، فأصبح الجسد مكافئا للغة، وبما أن الثعر انتهاك دائم لقانونية اللغة؛ فقد أدى ذلك إلى اعتبار الكتابة الثعرية ممارسة شهو انية: الشعرُ في جسد العشّاق موطنُهُ

r شعرية الكتابة والجسد- دراسة حول الوعي الثعري و النقدي، محمد

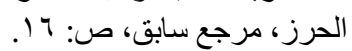

للشعر، و المعنى الثعري للقصيدة مفتوحا؛ نظرا للمتاهة التي تعتصر العالم/ المجتمع؛ >(فالجسد كنص من خلال علاقته بالو اقع و الحياة و التاريخ ينطوي، أو يتضمن، على بنيات أنثروبولوجية لا تنفك تؤثر على سلوكيات المجتمع، و على علاقاته الداخلية (اللغة) والخارجية (الواقع)، وقد تتعاضد بنيات الداخل والخارج لتفضي في النهاية إلى بنية جسدية قائمة باعتبارها أبرز العوامل المؤثرة في إنتاج المعنى، سواء أكان على مستوى النصوص ذي الوعي الجمالي ـالمعرفي داخل اللغة، أو على مستوى النصوص السلوكية خارج دائرة اللغةها'، وبهذا الدور الوظيفي الاجتماعي للجسد تشتبك الوظائف التي يتشكل من خلالها \المعنى الإبداعي للشعر عن جاسم الصحيح《)، الأمر الذي يزيد من تعقده من جهة، ويسلم إلى النوع الآخر من الوظائف من جهة ثانية.

والجسد ـمن جهة أخرى- دال على اللغة، واستعارة عنها؛ فهو دورها الوظيفي الذي تمارسه في الوجود؛ إذ \اللغة نظام وسيط يتم من خلاله التعبير عن الفكر أو تجسيدهاء'. وبهذا، و على الرغم من وظيفة دال 》الجسد《) الاجتماعية، فهو يؤدي وظيفة أخرى شعرية -واللغة (الرسالة) وظيفتها

\footnotetext{
' شعرية الكتابة والجسدـ دراسة حول الوعي الثعري و النقدي، محدد

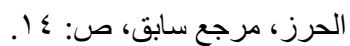

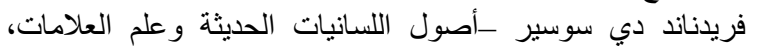

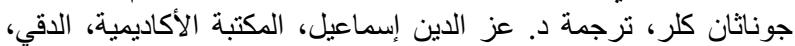

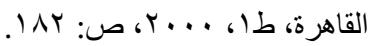


كعامل كامن ومستمر في الثعر من خلال الدال (ما يزال). ويؤكد الثناعر فاعلية الجسد من خلال قدرته على إثارة النشوة؛ حيث يقول: للكَ من خيالِكَ

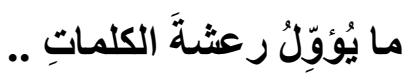

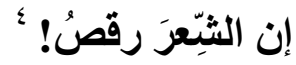

الرقص هو فن استكثاف الجسد، وهو ما يعني أن الشعر استكثاف دائم من خلال دخوله المستمر في علاقة، كما يربط الثعر بالغاية الإمتاعية الجمالية التي اختُصرت فيها البلاغة قديما، والتي اتخذت من الشعر ميدان بحثها في الظاهرة؛ حيث ا(تثير ماك روبي إلى عدد من المستويات

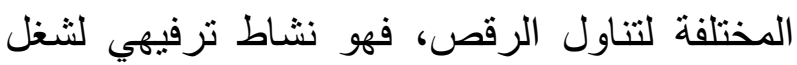
أوقات الفراغ، ومصدر من مصادر المتعة الجنسية التي تعم الجسد كله، كما أنه شكل من أثكال التمرينات الرياضية. و على النقيض من ذلك، قد يكون الرقص شكلا من أنثكال التحكم في جسد الأنثى وحركتها من خلال تأكيده أهمية رشاقة الجسد

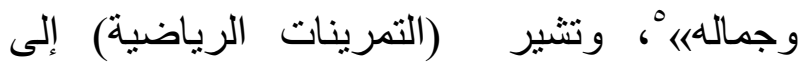

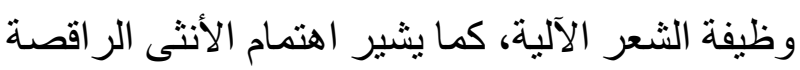
بجسدها إلى ضرورة رعاية الثاعر بقصيدته واعتنائه بها، ومعاودته النظر فيها مرة تلو أخرى، بوصف الرقص استعر اض يثير الذات ويستفز ها.

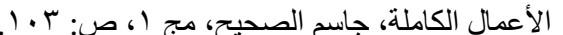

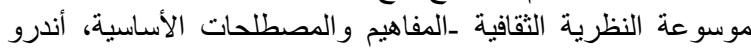

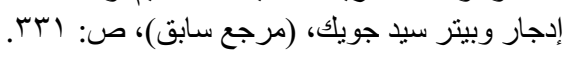

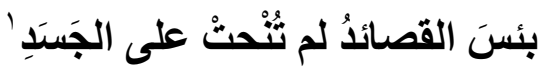
ويعني نحت القصيدة على الجسد ضرورة اعتبار الموقعة المكانية في بنائها، كما يعني ــن خلال العلاقة رجل-امرأة(جسد)، و التي شغلت مساحة كبيرة في الثعرية العربيةـ التلاحم الحميمي لهي بين المتمايزات: اللغة_ الأفكار- الحبر_الورق، والذي يمارس النص من خلاله لذته وشهوانيته بتعبير بارت، وتنقلنا كذلك إلى عو الم الصوفية، وهو نقل تدعمه ثنائية الجسد الستر التي تنقل ضمنا إلى الستر السر، والسر ميدان انتغال القلب الصوفي العرفاني، وهو واحد من الأصول التي أسست لمبدأ الانفتاح سابقا، ويستعين الصوفي على الستر بالرمز و الخيال؛ >(فالصوفي باختياره الرمز، وذهابه صوب الخيال، باعتباره إسراء نحو اللامتناهي، كان يحاول كتابة السر، وكتابة السر تعني لديه تجسيد المساعي

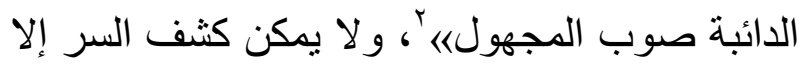
بالتلاحم ، يقول 》الصحيح《): ها أنتَتَ عُدْتَ

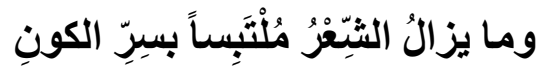
يبحثُ عن صلاةِ في الوجودِ

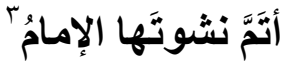
هنا، نشتغل الدوال (ملتبسا - سر - نشوة) في ترسيخ عامل الثهوة التي يثيرها دال الجسد

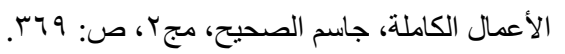

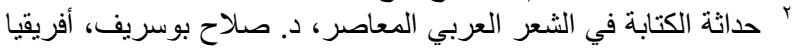

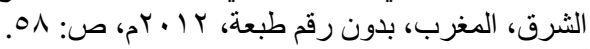

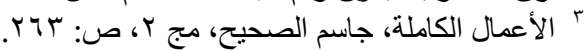


ومفيد جدا استثمار اقتراح عالم الاجتماع

الأميركي روبرت ميرتون في تميزه بين الوظائف الظاهرة والوظائف المستترة أو الكامنة والذي يفضي إلى كون الوظائف الكامنة ناتجة عن انعدام الوعي (المقصدية) من جهة فاعليهاء، وهو ما يعني بالضد أن الوظائف الظاهرة تعني الوعي و المقصدية؛ مما يجعلها وثيقة الصلة، بتحديد المعنى الإبداعي عن شاعر ما؛ ومن ثم تصلح لأن تكون مدخلا مناسبا لهذا الغرض. ويمكن فحص عدد من الدوال، واستثمار ها، والتي تعلن عن وظائف اجتماعية للشعر؛ لتسهم بدور ها في تشكيل معناه الإبداعي، ومنها: - - الثعر ثورة/ غضب/ رفض الشعر بوصفه ثورة هو مجال مناسب لإعلان الرفض والغضب، وهو أمر ناتج عن الوعي الجديد للثاعر المعاصر بالمدينة؛ حيث الينتج الوعي المديني حال تمرده على علاقات المدينة القمعية قصيدة الرفض، وطبيعي أن تبدأ قصبدة الرفض بالسياسة غالبا؛ ولكن قصيدة الرفض لا تتوقف على السياسة غالبا، و إنما تمتد إلى غيرها من المدارات الضـاغطة للوجود الإنساني»؛ ذلك الوجود الثـاغل للإبداع الفني بشكل عام، والثعر خصوصسا. إلا أن دخول الغضب في دائرة الإبداع، وإن كان يحمل

موسوعة النظرية الثقافية ـالمفاهيم والمصطلحات الأساسية، أندرو

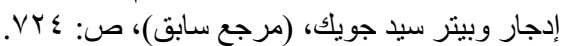
• قصيدة الرفض ـقراءة في شعر أمل دنقل، جابر صنابر عصفور، الهيئة

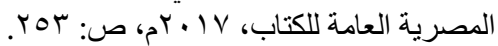

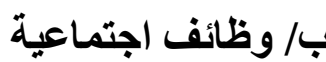

تفصح تواصلية جاكبسون من خلال

عناصر ها الثلاثة: المرسل ـ المرسل إليه ـ السياق عن وظيفة/ وظائف اجتماعية تؤديها الرسالة الشعرية'؛ بل لقد >|ظلت الوظيفة تمثل النموذج النظري المسيطر في ميداني الأنثروبولوجيا الثقافية و علم الاجتماع على امتداد النصف الأول من القرن العشرين. وتحاول الوظيفة -في جو هر ها- أن تفسر أي نظام أو مؤسسة اجتماعية أو ثقافية في ضوء النتائج التي يحدثها هذا النظام أو هذه المؤسسة بعينها على المجتمع ككله" '، ويعني ارتباط الوظيفة بتفسير النظام كونها جزءا من معناه أو ماهيته؛ حيث اختصر الشكلانيون معنى الثعر في نظامه، وإن كانوا تبنوا مبدأ الفن لذاته منحيين الجانب الاجتماعي. فإن الثعر بوصفه نظاما من العلامات، ومن حيث كونه نظاما فهو يرتبط بالوظيفة (الاجتماعية)، ومن حيث كونها علامة فإن الطبيعة العلائقية للعلامة قد مكنت اللغة/ الثعر من أداء وظيفة اجتماعية كذللك؟.

يصرح جاكبسون بكون الفن لبنة في الصرح الاجتماعي، ومكون الجئي

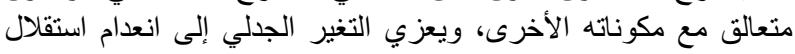

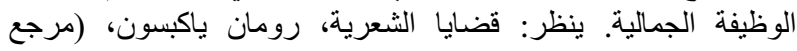

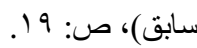
موسوعة النظرية الثقافية ـالمفاهيم والمصطلحات الأساسية، أندرو

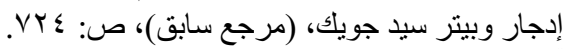

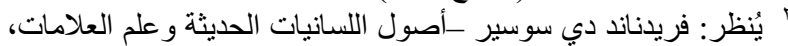

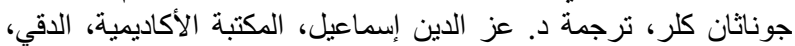

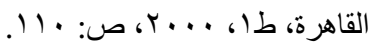


بيني وبين الأمنياتِ، وإنْ عَلا!' إن استعمال الجار (في) بدلالته الظرفية ينتج معنى اعتبار الثعر هو المكان الوحيد الذي يخترق الأمواج، ويتجاوز إلى الأمنيات، وهو يعني رغبة جارفة للثاعر في البحث عن مكان آمن ينقذه مما يحيط العالم الخارجي جميعه من شقاء و آلام. والأمر في مسألة الرفض لا يقتصر على الرفض الاجتماعي، و إنما يبدأ في عالم الثعر من الرفض البنائي الذي مثلته وظيفة الانزياح، و التي دفعت بالثاعر إلى تبني الرفض الدائم للقار والثابت والتقليد؛(|فالنظرة التقليدية تقوم أساسا على قبول العالم كما هو؛ ومن ثم فإن وظيفة الثعر في هذه النظرة هي استعادته، ووصفه ومحاكاته لا غير، والإبقاء على صورته. في حين أن النظرة الحداثية تنبني أساسا على رفض العالم، وإعادة النظر فيه جذريا، وخلق عالم مغاير وجديد، عالم البحث و التساؤله"، وما دام الأمر مرتبطا بإعادة النظر فهو يعني التقرير بهيمنة مبدألرؤيا/ الرؤية الذي لو لاه ما أدى الشعر وظيفته الشعرية المهيمنة؛ فكلاهما وجه لآخر. ويترتب، إذن، على مبدأ الرؤيا/ الرؤية طبيعة الثعر الرافضة، ثم طبيعته الدرامية، التي تجعل من

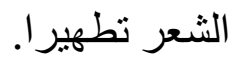

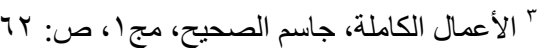

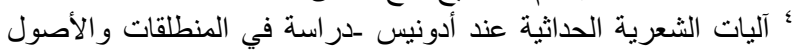

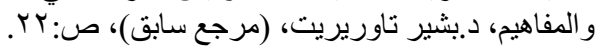

سيفه المسلط، يحمل معه قلب الثاعر النابض الذي يمتاز به عن غيره؛ فيلجأ إلى القصيدة بما بمكن أن تحميه وتحمل ما بدخله كذللك إلى جمهوره؛ ليحيي في نبضه الثورة، وهو ما عبّر عنه 》جاسم| حين قال: - 20 - n

\section{وثََََََة في القصيدةِ خيرُ مرعَى أُسَرِّحُ فيهِهِ غزلانَ انفعالِي'}

يؤكد 》جاسم/ من خلال دواله وظيفة اجتماعية يؤديها الثعر، وهي بالأساس نتاج تحول في الوعي بالمدينةُ التي يثير إليه الظرف المكاني (ثمة)، وهو يؤكد حيرة الثاعر ولهثه النضالي الطويل النابع من حنينه إلى الصفاء القروي الحالم الذي كان يعيشه نظيره قديما كما يبرزه الدالان (مرعى - غزلان)، ومن مجموع الدوال يثير الثـاعر أزمة الزمكانية لديه؛ فالقهع المدني الناتج عن الانهماك في المادية في العصر الحاضر، شكل و عيا مخالفا بالمدينة؛ مما دفع الثاعر إلى اتخاذ الثعر بما يحمله من قدرة على احتمال الضدين: الغضب و الوداعة، فيستصفي نفسه من آلامه؛ فيبرز ها من خلال الثعر ؛ ليطهر نفسه منها. و الرفض وجه التحدي الآخر، ونقيض اليأس والاستسلام؛ لذا يقول 》جاسم/《: في الشعرِ لايأسنُ يَحُولُ بمَوجِهِ

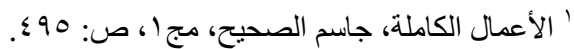

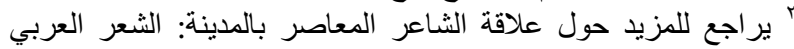

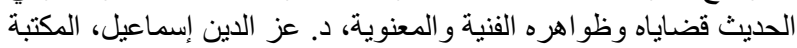

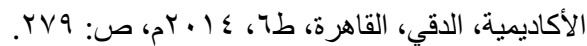


اللحظة الحاضرة؛ بل هي آتية من بعيد، وتغريبتنا لم تبدأ هنا والآن، وإنما رافقت جميع مراحل تشكيل مخيلتنا الذي ظل هو الآخر مصسادرا مغيبا واقعا هنالك بعيدا في منطقة اللامفكر فيهی)؛، وهو ما عناه

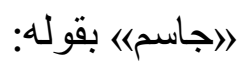

حاثَا القصيدةَ أنْ تكونَ هُوِيَّتي حنَّى تكونَ صدى الثَّقَاعِ الآدميْ هنا، يرفع الثاعر الثعار نفسه الذي رفعه

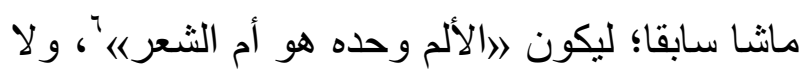
يمكن تخفيف الوجع وتطهير النفس إلا بالمساحة التي يفتحها ويسمح بها الشعر؛ لتكون ملاذا، يقول

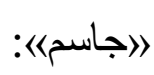
أحتاجُ القصيدةً كي أُطَّبَبَ بعضَ أوجاع الحقِقةِ تحث تخديرِ المجازِ لعلَّني يومًا أطيقُ من الأسىى ما لا أطيق ن فمنطقة المجاز هي المساحة التي يفتحها الثعر؛ فهي في صفاتها الذاتية تحمل بداخلها مغايرة الثابت، والجنوح إلى الخيال الحالم، و إذكاء العقل

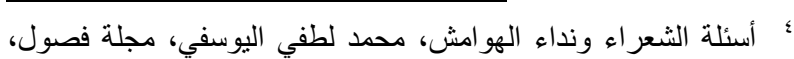

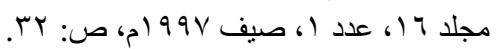

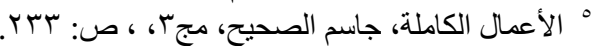

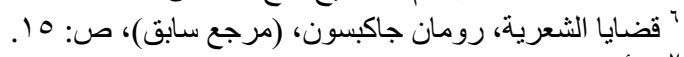

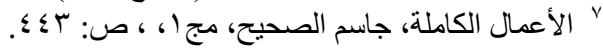

- - الثورة تطهير

حدد أرسطو -في قسمته للأنواع الثعريةمهمة التطهير للمأساة'، بصرف النظر عن توزيعه التراجيديا والكوميديا بين الخير والثر؛ لكن المهم الآن هو كون التطهير وظيفة يؤديها الثعر، و لأجلها ترسبت بداخله جينات درامية ملأته بالحركة و الموضوعية و التجسيد'. . ويستثرر الثاعر دال 》الجرح|《ن أجل إبراز الوظيفة التطهيرية للشعر، وهي مهمة اجتماعية لا يريب؛ نظرا لارتباطها بالفو اعل والأحداث، وكلاهما أساس بنية المجتمع، يقول: - 20 - 20

\section{أحبُّكِ إذْ تستشَفِينَ حزني

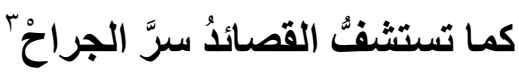
إن صناعة الحاضر و استشر اف المستقبل لا تتحقق على ركامات التاريخ الإنساني كما هي، و إنما بالدخول فيه لتطهيره وتخفيف أوجاعه و آلامه، وهو أمر لا يتأتى إلا بإعادة نكأ الجرح مرة بعد مرة؛ >(فتحرير الذات الكاتبة ودفعها على دروب التأسيس الحقيقي لا يمكن أن يتم إلا مرورا بتحرير ذاكرتها

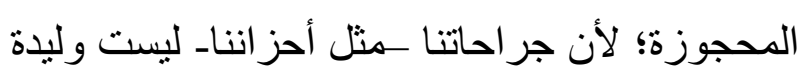

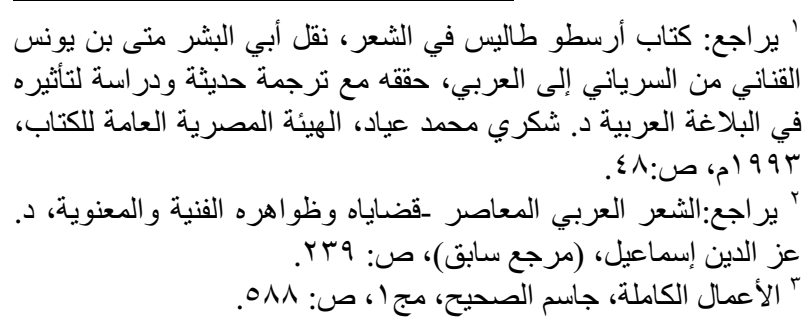


وأول المواجهة السفارة؛ لذا كان الثُعر ارتحالا وسفرا دائمين، وهو أمر وطّأ له بكاء الطلل في القصيدة القديمة، والذي يعني أول ما يعني الوقوف على الماضي واستعباره، بعد الرحيل عنه. و السفر والسفارة شقيقان ونسيبان؛ لذا فالثعر بريد من الذات إلى الآخر / العالم من أجل تحقيق الرغبة الحالمة في الاستقرار الذي لا يتحقق؛ نظرا لطبيعةالإنسان الذي جبل في كبد ومشقة؛ ومن ثم لا يجد غير الثعر سفيره للسلام، وهو أمر أنجزه الثعر هُهر حقيقة في مواقف متعددة، لاسيما في الاعتذاريات التي حقنت بها دماء كثيرةكما تظهره اعنذاريات النابغة وبانت سعاد لكعب بن زهير؛ بل كان الشعر عامل تزكية لسلوكيات مسالمة كما فعلت معلقة زهير؛ لذا يقول 》اجاسم):

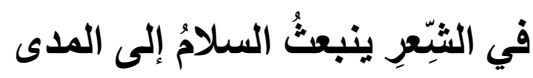

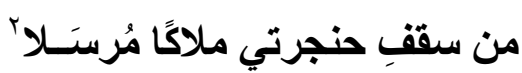
وبإنجاز السلام عبر الثعر يتحقق للثاعر سلامه النفسي الذي أعلن من خلاله ثورة التطهير

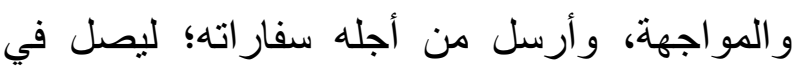
الأخير إلى هدنة لا تلبث غير لحظة خائبة تعكر صفوها الثورة من جديد؛ فيعيد الثاعر كرته في أبد استمر اري لا يتوقف: وهذي القصيدةُ ليستْ سوى هُدنة الِّة
بعملها في الذهن، والجسد بتوسلها بالبصر. إنها، إذن، الوجود الإنساني في كينونته.

\section{- - التطهير مواجهة}

و التخدير الذي يحدثه الثعر في الإنسان ليس تثبيطا، وإنما هو المرحلة الأولى من مراحل الإفاقة التي ينشدها الثشاعر بعد عملية التطهير التي نكأ فيها الجرح، فمن خلالها واجه الثاعر ذاته وتاريخه بما احتمله معه من مأساة الأمس التي تتكرر كل بوم كما ولها هي، وانتقل بها إلى الوعي بضرورات المواجهة التي لا يمتلك الثاعر فيها غير التسلح بالثشعر؛ لصد

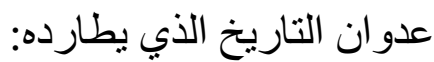

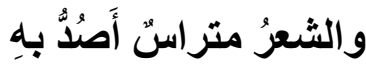

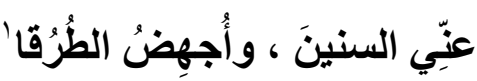
فتكرار المأساة التي مر فيها التاريخ العربي ، دون إهمال اللحظات المضيئة في هذا التاريخ، و هي كثيرة، هذا التكرار على مدى الزمن، وتوطنه في المكان ربما كان دافع الثعر إلى الابحث الدائم في اللازمان واللامكان، وهو بحث ينتقل من حدة المواجهة مع قيود الزمان والمكان، إلى وداعة الحلم و السفر إلى لا نهاية. - - المواجهة سفارة 
المبدأ الأساس الذي تصدر عنه شعريات الحداثة، وتنبثق منه المبادئ الماورائية الأخرى، كالانفتاح و المفاجأة و السؤال و الغموض، و التي مثلت السنن الذي تحاك القصيدة على مناويله؛ ومن ثم فإن الوظائف التي تتحقق من خلالها أدبية الثعر تنبثق

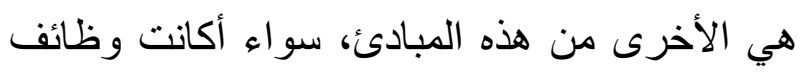

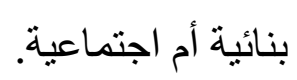

- الوظائف: تتجلى الوظائف في أمرين:

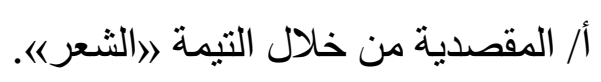

ب/ التمثلات التي ينتقل فيها النص من الوعي

$$
\text { (الماور اء) إلى الوجود (التمثل). }
$$

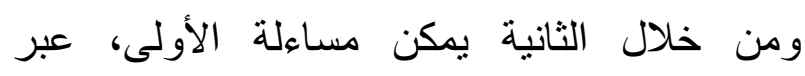
النصوص التي وردت فيها التيمة 》الثعرش《ن نفسها.

$$
\text { وقد توز عت الوظائف في قائمتين: }
$$

1) وظائف بنائية: رأى الثكلانيون أن ما يجعل من عمل ما عملا أدبيا أمور كامنة في علاقات العناصر

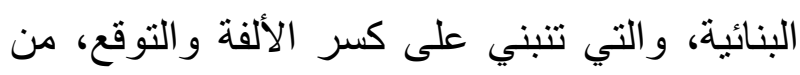

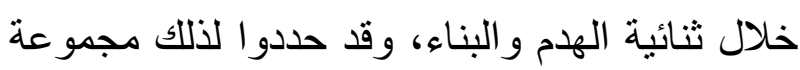
من الوظائف، وقد لمس الباحث وعي 》اجاسم) بها،

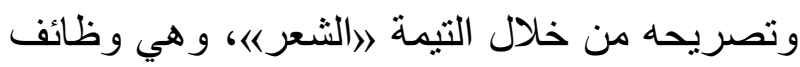
تتوزع بين الآلية والانزياح و الهيمنة والتناص، ومن وهن خلال مساءلة المعنى الإبداعي الوارد في السياق اللغوي للتيمة 》الثعر)، عبر امتحان منجزه بتحليل

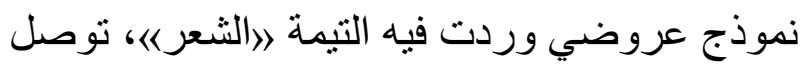
الباحث إلى عدة نتائج هي:
بين قلبي ولحظتيَ الخائبةُ إن هدنة الثشاعر ومر احه وراحته، و إن كانت في القصيدة، فإنها لا تلبث إلا أن تأتي على أعقابها مرة أخرى؛ حيث يظل الشعر في دينامية دائرية يوصل بعضها إلى بعض، وينجز بعضها بعضا،

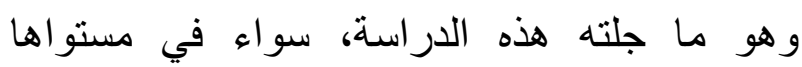

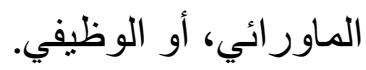

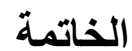

ليست الخاتمة مجرد تقليد منهجي، و إنما مكوّن بنائي يستخلص غايات البحث ويعيد مساءلة إجر اءات البحث في ضوء غاياته، وقد سعى الباحث من خلال تتبع تيمة 》الثعر|《 إلى استكثناف 》المعنى الإبداعي للشعر عند جاسم الصحيح)، وقد اتخذت الدراسة لنفسها مسارين مشتبكين معا، هما: النقد الموضوعي شكلا، و العلاماتي النسقي إجراءً، ومن خلال المنهجين وجد الباحث أن الالمعنى الإبداعي للشعر عن جاسم الصحيحه يتوزع بين مسارين:

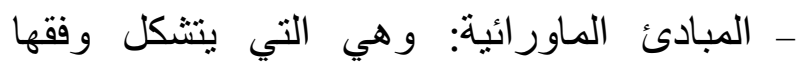
المعنى الإبداعي للشعر عن جاسم، وقد وجد الباحث من خلال تتبع التيمة شعر ، ومن خلال المبادئ التي

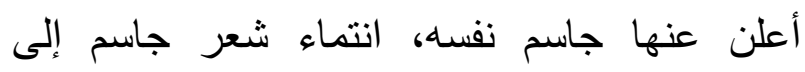
التصور الحداثي للشعر؛ حيث شعرية الحداثة تنظر إلى الثعر بوصفه رؤيا/رؤية خاصة للعالم، وهو الأعمال الكاملة، جاسم الصحيح، مج(، ، ص: لrV. 
وبنائياته، الأمر الذي يمكن تلمسه في دراسات أكثر سعة من خلال مساءلة العناصر البنائية للشعر نفسه، إن إيقاعا، أو لغة، أو صورة، أو تناصا، ...إلخ، وهو أمر خارج قدرة مثل هذه الدراسة، وخارج غاياتها، و إن كانت الدراسة حاولت تلمس بعض ذلك على وجه العجلة التي تحاول استدر اكها بمثل هذا التنويه.

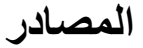

ـ الأعمال الكاملة، جاسم الصحيح، مجلد ا، دار أطياف للنشر و التوزيع، القطيف، طا، 10 • بام ـ الأعمال الكاملة، جاسم الصحيح، مجلد ب، دار

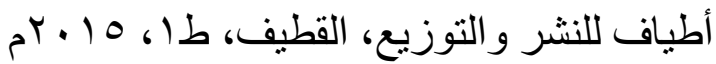
ـ الأعمال الكاملة، جاسم الصحيح، مجلد بّ، دار

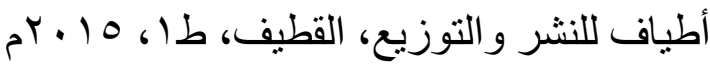

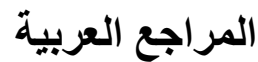

ـ آليات الثعرية الحداثية عند أدونيس -ـدراسة في المنطلقات والأصول و المفاهيم، بشير تاوريريت،

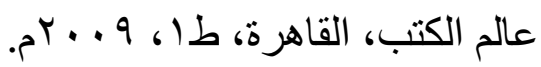
ـ الإبهام في شعر الحداثة ـالعوامل والمظاهر

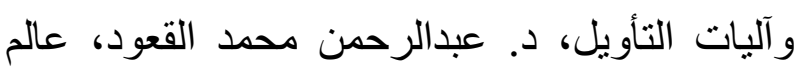
المعرفة، المجلس الوطني للثقافة والفنون والآداب،

$$
\text { الكويت، ب +. r. م. }
$$

ـ البلاغة الجديدة بين التخييل و التداول، د. محمد

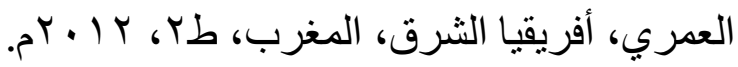

ا- خروج المعنى الإبداعي للشعر عن جاسم عن الأحادية إلى التعددية، من السمع إلى البصر، من الابعي الثفاهي إلى الكتابي؛ حيث حضرت الكتابة لتعلن عن نفسها بطريقتين: الأولى: فعاليتها في إعادة تشكيل الصوتي، من خلال تغليب اللغة والثكل الكتابي على الإيقاع العروضي. الثانية: حضور ها الذاتي البصري. وترتب على العلاقات البنائية بين العناصر تجلي الوظائف الثناثة البنائية الأولى، وهي: الآلية،

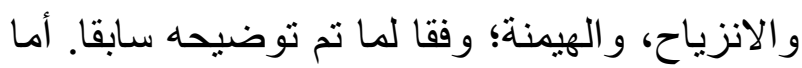
عن التناص فقد حاول الباحث التدليل عليه من خلال العلاقة: الثعر ــطفل، والثعر-وردة، بين كل من جاسم وأدونيس على سبيل المثال، مع الإلماح إلى التشابه الكبير الذي يمكن أن يدخل في دائرة التناص بين المعنيين الإبداعيين للشعر عند الثاعرين، الأمر الذي يؤكد وجهة جاسم الحداثية. Y) وظائف اجتماعية: وبوصف الثعر في تمثلة

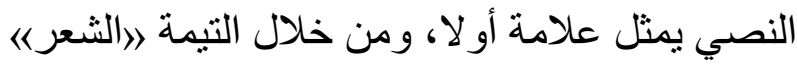
ثانيا؛ فإنه ذو طابع اجتماعي، وقد تلمس الباحث عددا من الوظائف الاجتماعية للشعر، وهي: الثورةالتطهير - المواجهة_ السفارة. وفي الأخير، ومن خلال امتحان تيمة 》الثتعرهي عبر مساءلة المنجز الإبداعي للنصوص التي وردت فيها يمكن القول بأن 》المعنى الإبداعي للشعر عند الندي جاسم الصحيح《) يستقي من الحداثة أصوله ومفاهيمه 
- الثعر العربي الحديث قضاياه وظواهره الفنية و المعنوية، د. عز الدين إسماعيل، المكتبة الأكاديمية،

$$
\text { الدقي، القاهرة، طج، ع ا • ب م. }
$$

- شعرية الجسد -دراسة نقدية في أعمال محمد عفيفي مطر الثعرية، شوكت المصري، الهيئة المصرية العامة للكتاب، ب I ـ بم. - شعرية الكتابة و الجسد- دراسة حول الوعي الشعري والنقدي، محمد الحرز، مؤسسة الانتشار

$$
\text { العربي، بيروت، لبنان، طا، } 0 \text {. . ب م. }
$$
- صدع النص وارتحالات المعنى، إبر اهيم محمود، مركز الإنماء الحضاري، حلب، طا، ... ㄷ․ - الصوت القديم الجديد ـدراسات في الجذور العربية لموسيقى الشعر الحديث، د. عبد الله الغذامي، الهيئة المصرية العامة للكتاب، 9AV ام. - الصوفية و السوريالية، أدونيس، دار الساقي، بيروت، طا، بدون تاريخ. - ظاهرة الثعر المعاصر في المغرب ـمقاربة بنيوية تكوينية، محمد بنيس، دار توبقال للنشر، طس،

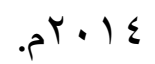

- الغموض في الثعر العربي الحديث، إبراهيم رماني، ديوان المطبو عات الجامعية، الجزائر، بدون تاريخ. - فاتحة لنهايات القرن -بيانات من أجل ثقافة عربية جديدة، أدونيس، دار العودة، بيروت، طا، ، 9 (م.
- التفكير بالعين، سعيد العفاسي، دار الوطن

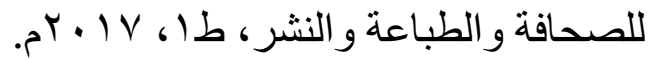
- الثابت و المتحول-بحث في الاتباع و الإبداع عند العرب، الجزء الثالث (صدمة الحداثة)، دار العودة،

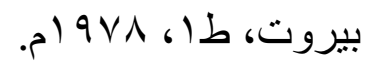
- جدلية الخفاء و التجلي، كمال أبو ديب، دار العلم

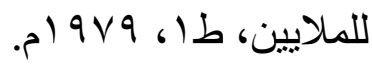
- حداثة السؤال (بخصوص الحداثة العربية في الثعر و الثقافة)، محمد بنيس، المركز الثقافي العربي، بيروت، طن، 9 إم. - الخبرة الجمالية دراسة في فلسفة الجمال الظاهراتية، د. سعيد توفيق، المؤسسة الجامعية

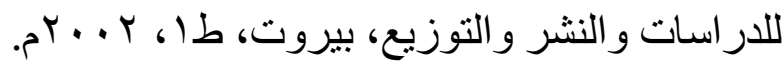
- الروح الحية- جيل السنينات في العراق، فاضل العزاوي، دار المدى للثقافة والنشر، دمثق-بيروت،

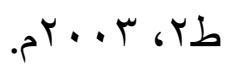
- زمن الثعر، أدونيس، دار الساقي، بيروت، طV، r - سيموطيقا التشبيهـ- من البلاغة إلى الثعرية، د.محمد فكري الجزار، نفرو للنشر والتوزيع، طا، . - السيميائيات و التأويل، مدخل لسيميائيات ش.س.بورس، المركز الثقافي العربي، الدار

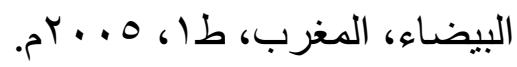


- مقدمة للشعر العربي، أدونيس، دار العودة،

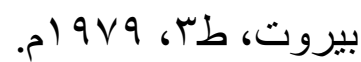

- المنحى الوظيفي في الفكر اللغوي العربي الأصول والامتداد، دار الأمان، الرباط، طا، لئك . Y T T ـ ـ من فلسفات التأويل إلى نظريات القراءة ـدراسة تحليلية نقدية في النظريات الحديثة، عبد الكريم شرفي، منشورات الاختلاف، الجزائر، طا، بدون

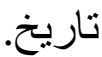
- موسيقى الحوت الأزرق: الهوية_الكتابة_العنف، أدويس، دار الآداب، بيروت، طا، ؟ +. Yم.

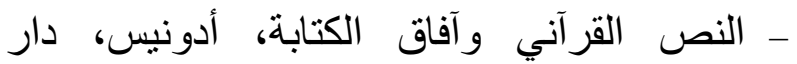

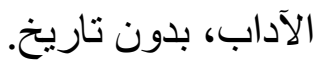

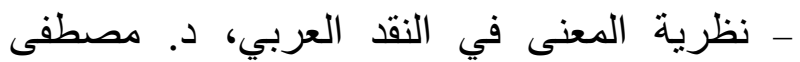
ناصف، دار الأندلس للطباعة و النشر، بيروت، طب، . 9191 - النقد الأدبي الحديث، د. محمد غنيمي هلال، دار الثقافة ـ دار العودة، بيروت، لبنان، بدون ط، plavr - نظرية البنائية في النقد الأدبي، د. صلاح فضل، مكتبة الأسرة، بدون رقم طبعة، القاهرة، ؟ +. ץم.

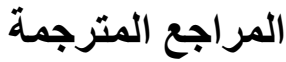

- بنية اللغة الثعرية، جان حوهين، ترجمة محمد

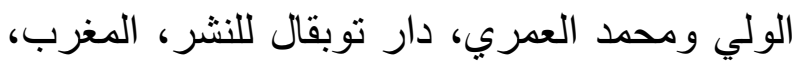

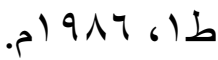

- قاموس مصطلحات التحليل السيميائي للنصوص، رشيد بن مالك، دار الحكمة، الجزائر، ... ب م. ـ قراءة النص- تأصيل نظري وقراءات تطبيقية، د. عبد الرحيم الكردي، سلسلة كتابات نقدية، الهيئة

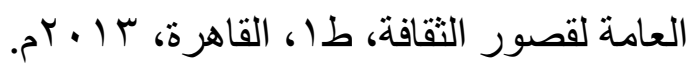
ـ قصيدة الرفض -قراءة في شعر أمل دنقل، جابر

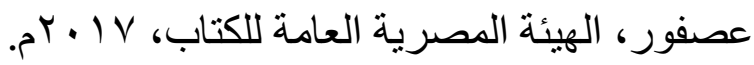
ـ الكتاب ـأمس المكان الآن، أدونيس، دار الساقي، بيروت، جا، طا، 990 ا، جr، طا، 991 ام،

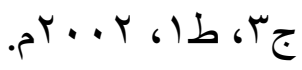
ـ كتابة المحو، محمد بنيس، دار توبقال للنشر، الدار البيضاء، المغرب، طا، ـ99 (9م. - المصطلحات الأساسية في لسانيات النص وتحليل الخطاب ـدراسة معجمية، د. نعمان بوقرة، عالم الكتب الحديث، الأردن، طا، 9 . . ب م. - معجم المصطلحات الأدبية المعاصرة، د. سعيد علوش، دار الكتاب اللبناني، بيروت، طا، 910 ام. - معجم مصطلحات العربية في اللغة و الأدب، مجدي وهبة و وكامل المهندس، مكتبة لبنان،

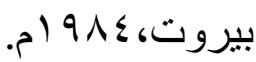
- مفاهيم موسعة لنظرية شعرية: اللغة - الموسيقى ـ الحركة، الجزء الثالث (أنغام ورموز)، د. محمد مفتاح، المركز الثقافي العربي، الدار البيضاء،

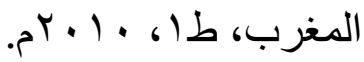


- فهم الفهم -مدخل إلى الهيرمينوطيقا (نظرية التأويل من أفلاطون إلى جادامر )، د. عادل مصطفى،

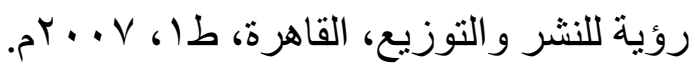
ـ قضايا الشعرية، رومان جاكبسون، ترجمة محمد الولي ومبارك حنون، دار توبقال للنشر، الدار البيضاء، المغرب، طا، 911 ام. - كتاب أرسطو طاليس في الثعر، نقل أبي البشر متى بن يونس القناني من السرياني إلى العربي،

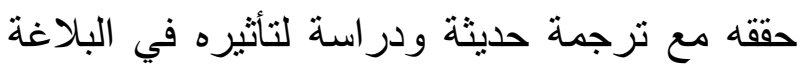
العربية د. شكري محمد عياد، الهيئة المصرية العامة للكتاب، س 999 (م. ـ الكتابة والاختلاف، جاك دريدا، ترجمة كاظم جهاد، تقديم محمد علال سيناصر ، دار توبقال للنشر ،

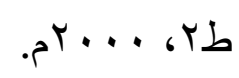
- محاضرات في علم اللغة العام، فريديناند دي سوسير، ترجمة د. يوئيل يوسف عزيز ، ومر اجعة د. ماللك يوسف المطلبي، سلسلة آفاق عربية، ع ז، دار آفاق عربية، الأعظمية، بغداد، طس، 910 ام. - مداخل إلى التفكيك (البلاغة المعاصرة)، جالك ديريدا وبول دي مان وآخرون، تحرير وترجمة: د. حسام نايل، تصدير د. محمد بدوي، الهيئة المصرية

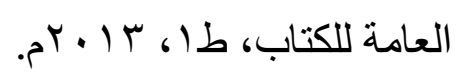
- مدخل لجامع النص، جيرار جينيت، ترجمة عبد

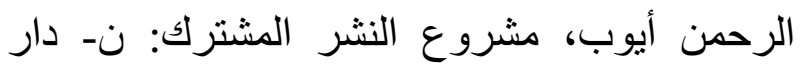

- تحليل النص الثعري -بنية القصيدة، يوري لوتمان، ترجمة د. محمد فتوح أحمد، دار المعارف، لهنه . 1990 - الحداثة، نصوص مختارة، إعداد وترجمة محمد سبيلا و عبد السلام بن عبد العالي، دار توبقال للنشر، الدار البيضاء، طا، 997 (م. - السيمياء والتأويل، روبرت شولز، ترجمة سعيد الغانمي، المؤسسة العربية للاراسات والنشر، طا، لهوناك

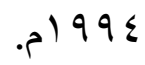
ـ الثكل و الخطاب ـمدخل لتحليل ظاهر اتي، محمد الماكري، المركز الثقافي العربي، بيروت، طا، . 1991 - علم النص، جوليا كريسطيفا، نرجمة فريد الزاهي، مراجعة عبدالجليل ناظم، دار توبقال

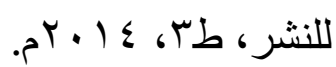
- فريدناند دي سوسير ـأصول اللسانيات الحديثة وعلم العلامات، جوناثان كلر، ترجمة د. عز الدين

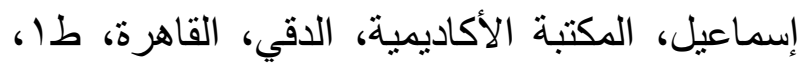
. r... - فكرة الفينومينولوجيا، هسرل، ترجمة فتحي إنقذو، المنظمة العربية للترجمة، بيروت، طا، r... - فهم فريدناند دي سوسير وفقا لمخطوطاته، لويك دوبيكير، ترجمة ريما بركة، مراجعة بسام بركة،

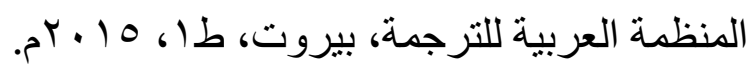


- نظرية المنهج الثكلي -نصوص الثكلانيين الروس، ثرجمة إبراهيم الخطيب، الثركة المغربية للناشرين المتحدين، مؤسسة الأبحاث العربية، طا، . $9 \wedge r$

- الوجودية، جون ماكوري، ترجمة د. إمام عبد القتاح إمام، مراجعة . فؤاد زكريا، سلسلة عالم المعرفة، المجلس الوطني للتقافة والفنون والآداب،

$$
\text { . } 9 \wedge r \text { ، OA }
$$

الدوريات

- أسئلة الشعراء ونداء الهوامش، محمد لطفي اليوسفي، مجلة فصول، المجلد السادس عثر، عدد

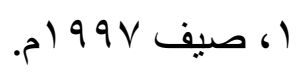

- الخطاب الثعري الحديث، رضا بن حميد، مجلة فصول، المجلد الخامس عشر، عدد ب، صيف

$$
\text { . ) } 997
$$

- فكرة السرقات الأدبية ونظرية التناص، عبد الملك مرتاض، علاقات، الجزء الأول، المجلد الأول، مايو

$$
\text { . } 1991
$$

- وجود النص الأدبي/ نص الوجود، مصطفى الكيلاني، مجلة الفكر العربي المعاصر، بيروتـ

$$
\text { باريس، عدد ؟0، } 911 \text { أم. }
$$

الثؤون الثقافية العامة- بغداد/دار توبقال للنشر، بدون تاريخ، ورقم الطبعة. - معايير تحليل الأسلوب، ميكائيل ريفاتير، ثرجمة وتقديم وتعليقات د. حميد لحمداني، منشورات دار سال، دار النجاح الجديدة، البيضاء، طا، س99 (م. - المعنى الأدبي من الظاهراتية إلى التفكيك، وليم راي، ترجمة د. يوؤيل يوسف عزيز، دار المأمون للترجمة والنشر، وزارة الثقافة والإعلام، بغداد، ط - موسو عة كامبردج، ج^، من الثكلانية إلى ما بعد البنيوية، تحرير رامان سلدن، المشروع القومي للترجمة، المجلس الأعلى للثقافة، القاهرة، طاء . - موسو عة النظرية الثقافيةـ المفاهيم و المصطلحات الأساسية، أندرو إدجار وبيتر سيد جويك، ترجمة هناء الجوهري، مراجعة وتقديم وتعليق محمد الجوهري، المركز القومي للترجمة، القاهرة، طب، . - نظرية الأدب، تيري إيجلتون، ترجمة ثائر ديب، منشورات وزارة الثقافة في الجمهورية العربية السورية، دمشق، • 99 (م. 


\title{
Research Title : Creative Concept of Poetry in Contemporary Saudi Poetry - Jassim Al - Sahih as a Model.
}

\author{
Dr. Badr nada alotaibi \\ Arabic language Institute for Speakers of Other Languages- King Abdulaziz University
}

\begin{abstract}
The analysis of criticism-literary pathways to the poetic text: systematic and objective, each of its words and procedures, and belongs to the tracking of a certain theme to the second track. However, the theme of "poetry" is more problematic than being objectively related; it is presented in an applied practice in which it proclaims its existence and its operating systems, which makes the theme in question accountable through the text; however, one of the two tracks is possible in the systematic organization of the form. The study approaches the theme of "poetry" objectively in terms of its form; but in terms of analysis it takes from modern theories and methodologies, the semiotic mark in its forefront, and its philosophies, analytical tools to explore "the creative meaning of poetry in Jassim. alsohih"
\end{abstract}

Key Words : the meaning - poetry- creativity 